\title{
Validity and Reliability of the Korean version of the Communication Scale for Older Adults
}

\author{
Jin-Young Roh ${ }^{a}$, Seong Hee Choi ${ }^{\mathrm{a}, \mathrm{b}, \mathrm{c}}$, Kyungjae Lee ${ }^{\mathrm{a}, \mathrm{b}, \mathrm{c}}$, Chul-Hee Choi ${ }^{\mathrm{a}, \mathrm{b}, \mathrm{c}}$ \\ ${ }^{a}$ Department of Audiology \& Speech-Language Pathology, Daegu Catholic University, Gyeongsan, Korea \\ ${ }^{b}$ Catholic Hearing Voice Speech Center, Daegu Catholic University, Gyeongsan, Korea \\ ${ }^{c}$ Research Institute of Biomimetic Sensory Control Pathology, Daegu Catholic University, Gyeongsan, Korea
}

\author{
Correspondence: Chul-Hee Choi, $\mathrm{PhD}$ \\ Department of Audiology \& Speech-Language \\ Pathology, Daegu Catholic University, 13-13 \\ Hayang-ro, Hayang-eup, Gyeongsan 38430, Korea \\ Tel: +82-53-850-2541 \\ Fax: $+82-53-850-2540$ \\ E-mail: cchoi@cu.ac.kr
}

Received: October 20, 2021

Revised: November 29, 2021

Accepted: November 29, 2021

This study was supported by Daegu Catholic University (20211182).
Purpose: Aural rehabilitation has been used to reduce communication difficulties related to hearing loss and minimize their consequence in everyday life. Aural rehabilitation includes diagnosis and identification of hearing loss, provision of appropriate assistive listening devices such as hearing aids and cochlear implants, auditory training, speechreading, and communication strategies training. Communication strategies refer to a course of action taken to facilitate conversation interaction or to correct communication problems. Compared to other components of aural rehabilitation, communication strategies have not been focused on as a significant evaluation tool in spite of their importance in daily life. This study aimed to develop a Korean version of the Communication Scale for Older Adults (K-CSOA) originally designed by Kaplan et al. (1997) to evaluate the changes in communication strategies and attitudes. Methods: The K-CSOA was composed of communication strategies and communication attitudes. The Communication strategies have three subcategories of Facilitative (10 items), Repair (15 items), and Preparatory strategies (16 items). The communication attitudes have also three subcategories of Own Attitude (19 items), Family's Attitude (7 items), and Others Attitude (5 items). The validity and reliability of KCSOA were obtained with total sixty subjects consisting of thirty subjects with normal hearing and thirty subjects with different degrees of hearing loss with mean age of 72 years old ranging from 60 years old to 85 years old. Results: The validity and reliability of the K-CSOA were measured using Pearson's correlation coefficient, Cronbach Alpha coefficient, and independent t-tests. The correlation coefficients were high (.502-.984) between total means of K-CSOA and subcategories of K-CSOA. The internal consistency ranged from .802 to .930 for Communication Strategies and from .620 to .962 for Communication Attitudes. The test-retest correlation of the K-CSOA was .986 and .988 for Communication Strategies and Attitudes, respectively. The correlation coefficient was .784 between the K-CSOA and Korean Hearing Handicap for the Elderly (KHHIE). In addition, there were significant differences in Communication Strategies and Communication Attitudes between the normal hearing and hearing loss groups. Conclusion: These results indicate that $\mathrm{K}-\mathrm{CSOA}$ can be used as a useful clinical tool providing in-depth information regarding communication strategies and attitudes in Korean elderly people.

Keywords: Auditory rehabilitation, Korean version of Communication Scale for Older Adults(K-CSOA), Communication strategies, Communication attitudes, Validity, Reliability
현재 우리나라는 경제 수준의 향상과 의학의 발전으로 인해 평 균 수명이 길어지면서 2020년 현재 65세 고령인구는 인구의 $15.7 \%$ 이며, 향후에도 계속 증가하여, 2025년에는 $20.3 \%, 2060$ 년 $43.9 \%$ 에
이르러 우리나라가 초고령 사회에 진입할 것으로 전망된다(Statistics Korea, 2020). 고령이 될수록 신체·감각 기능이 약화되어 일반 적인 삶을 영위하는데, 여러 가지 어려움이 수반된다. 노인의 $89 \%$ 
가 만성질환을 가지고 있는데(Korea Institute for Health and Social Affairs, 2018), 관절염 및 고혈압과 함께 가장 흔한 3대 만성질 환인 청각기관의 약화로 인해 발생하는 청각장애가 있다(Lim \& Chae, 2011). 청각장애는 청력손실로 인해 타인의 발화를 이해할 수 없게 하여, 의사소통의 어려움을 유발한다(Suk, 2004). 이러한 의사소통의 어려움으로 인해 난청인은 타인과의 원만한 대인관계 를 가질 수 없고 생활에 필요한 정보들을 습득하기도 어렵다. 결과 적으로 우울증, 사회적 고립, 외로움, 삶의 질 저하 등을 초래한다 (Yorkston, Bourgeois, \& Baylor, 2010). 그러므로 난청인에게 초기 에 다양한 방법의 중재를 통해 청능재활을 제공하는 것은 중요하 다. 노년기에 발생하는 청력손실에 대한 중재로는 보청기 및 인공와 우와 같은 청각기기 및 청각보조기기의 사용과 개인 및 그룹 청능 재활 프로그램의 참여 등이 있다(Laplate-Lévesque, Hickson \& Worrall, 2011). 구체적으로 청각재활 프로그램에는 청력손실의 진 단, 적절한 청각기기 및 청각보조기기 제공, 청능훈련, 의사소통 전 략훈련, 상담, 의사소통 파트너훈련, 독화, 언어치료 등이 포함되어 야한다고 한다(Jang, Cho, Kim, \& Choi, 2018; Predergast \& Kelly 2002; Tye-Murray, 2009).

노인의 청능재활의 목적은 크게 세 가지로 나눌 수 있는데 그 첫 번째는 난청 노인이 성공적인 의사소통을 하기 위해선 청력손실이 있는 난청 노인이 스스로 청력손실에 대해 이해하고 적절한 청각기 기 및 청각보조기기를 착용하는 것이다. 두 번째 목적은 독화훈련, 맞춤형 청능훈련, 적절한 보장구 적합 및 상담 등을 실시하는 것이 고(Gordon-Salant, 2005; Sweetow \& Sabes, 2006), 세 번째 목적은 청력손실이 있는 노인들이 일상생활에서 대화를 나눌 때 의사소통 전략(Communication strategies)을 사용하여, 불편함이 없도록 하 는 것이다(Jang et al., 2018; Tye-Murray, 2009). 또한 청각장애를 평 가하기 위해서는 청력검사만으로 결과를 결정하기보다는 더 많은 다른 정보가 요구되며(Khoo \& Kim, 2000), 청능재활 및 보청기 적 합의 효과를 확인하기 위해서는 음향 및 심리적 이득을 측정하는 것이 중요하다. 보청기 적합의 효과의 측정 내용은 보청기 착용 전. 후의 수행능력, 음향적 이득, 심리사회적 이득 및 보청기 착용 만족 도 등이 있다. 보청기 적합의 객관적인 평가로는 실이측정(Real Ear Measurement, REM), 2-cc 커플러 측정, 청력역치 및 어음인지레벨 등이 있으며, 주관적 평가로는 설문지가 있다(Kim, Shim, \& Lee, 2016). 설문지를 통해 다른 정보들을 얻기 위해서는 구체적이고, 신 뢰성을 가진 설문지를 이용하여, 난청인의 현재 처한 어려움이나상 황을 분석하고 파악을 해야한다(Han, Lee Koo, \& Kim, 2015). 현재 국내에 개발된 난청 관련 설문지는 Chu 등(2012)이 개발한 보청기 사용 후 만족도 변화를 측정하는 설문지 Korean version of Inter- national Outcome Inventory for Hearing Aids (K-IOI-HA), Kim, Lee, Kim과 Kim (2018)이 개발한 Korean Client Oriented Scale of Improvement (K-COSI), Khoo와 Kim (2000)이 개발한 노인성 난 청자들의 청각장애지수를 측정하는 설문지인 The Korean Hearing Handicap Inventory for the Elderly (KHHIE), Kim 등(2016)에 의 해 개발된 보청기 이득을 평가하는 설문지 Korean Version of Profile of Hearing Aid Benefit (K-PHAB) 등이 있다.

청능재활은 의사소통을 습득한 이후에 난청으로 인해 개인의 의사소통능력을 상실하여 예전에 가졌던 능력을 회복하고자 하는 과정을 의미하며(Bahng, 2017), 청력손실이 있는 노인들에게는 일 상생활에서 적절한 의사소통 전략을 사용하도록 도와주어 일상생 활의 불편함을 줄이고자 수행되어진다(Jang et al., 2018; Tye-Murray, 2009). 청능재활 프로그램의 구성요소로는 청력손실의 진단, 적절한 청각기기 및 청각보조기기 제공, 청능훈련(Auditory Training), 의사소통 전략 훈련(Communication strategies training), 정 보전달 및 상담, 의사소통 파트너 훈련, 독화, 언어치료 연수 교육 등 이 포함되어야 한다(Prendergast \& Kelly, 2002). 청능재활의 구성 요소인 의사소통 전략 훈련은 다른 구성요소들에 비해 상대적으 로 중요하지만 한국의 재활분야에서 강조되지 못한 실정이다.

청능재활에서 의사소통 전략(Communication strategies)이란 의사소통 과정의 편리, 의사소통 증진, 의사소통 과정의 수정과 같 은 행위를 말한다(Suk, 2004). 의사소통 전략의 종류에는 촉진 전 략(Facilitative strategies)과 수정 전략(Repair strategies) 등이 있 다. 촉진 전략은 의사소통 구성 요소인 화자(Talker), 메시지(Message), 환경(Environment), 환자/청자(Patient)에 영향을 미칠 수 있 는 의사소통 전략을 말한다(Jang et al., 2018; Tye-Murray, 2009), 촉진 전략은 각각의 의사소통 구성요소에서 의사소통의 어려움이 있을 때 사용 가능한 전략들을 말하는데, 화자에게 영향을 미치는 첫 번째 촉진 전략으로는 지시 전략(Instructional Strategies)이 있 다. 지시 전략은 청력손실이 있는 사람이 의사소통 파트너(Communication partner)에게 자신을 보면서 분명히 말해 달라고 요청 함으로써 의사소통 파트너 구어 행동에 영향을 주고(Jang et al., 20181; Tye-Murray, 2009), 화자의 외모 또는 행동을 변화시켜 의사 소통 효과를 증진시킨다(Moseley \& Bally, 1996). 두 번째 메시지에 영향을 미치는 촉진 전략은 메시지 구성 전략(Message-tailoring strategies)이다. 메시지 구성 전략은 의사소통 파트너가 적절히 반 응하도록 개인의 말을 다시 고쳐 말하는 방식이다. "어제 저녁에 무 엇을 했나요?"와 같은 질문에는 다양한 답변이 제시되어 의사소통 단절 가능성을 높이기 때문에 “어제 수영하러갔나요?” 아니면 “자 전거 타러 갔었나요?”와 같이 청자가 선택 가능하도록 답을 구성 
하는 것이다. 또 다른 메시지 구성 전략은 초의사소통(Metacommunication)이다. 초의사소통이란 의사소통을 위한 의사소통을 말하는 것으로, 단지 말하고자 하는 것이 아닌 어떻게 말하는 것이 바람직한 결과를 나타낼 수 있을지를 고려하는 전략이다. 세 번째 메시지 구성 전략은 메시지를 이해했음을 나타내는 인식 제스처 (Acknowledgement gesture)이다. 특정 난청인들은 상대방과 대화 할 때 메시지를 이해하면, 머리를 흔들거나 끄덕이지만, 이해하지 못할 때는 그러한 행위를 중단한다. 또한 상대방의 말을 이해했음 을 나타내는 동작을 잘못 사용한다면, 부적응 의사소통의 형태인 알아들은 척하는 행동(Bluffing)이 나올 수도 있다. 알아들은 척하 기는 개인의 자존심(Personal vanity) 때문에 청각장애를 인정하기 를 꺼리기에 발생할 수 있다(Jang et al., 2108; Tye-Murray, 2009). 그 러나 의사소통에 대한 응답으로써 침묵 또는 회피는 체면을 세울 수는 있지만, 의사소통에는 효과적이지 않을 수 있다(Jaworski \& Stephens, 1998). 세 번째 의사소통 전략은 환경을 변화시키는 전략 인 구조 전략(Constructive strategies)이다. 구조 전략은 의사소통 환경을 향상시키며, 성공적인 의사소통을 위한 전략을 말한다. 환 경을 분석하고, 수정 및 활용할 수 있는 요소들을 확인한다(Jang et al., 2018; Tye-Murray, 2009). 마지막으로 환자의 메시지 수용에 미 치는 전략인 적응 전략(Adaptive strategy)과 예기 전략(Anticipatory strategy)이 있다. 적응 전략이란 부적응 행동이 발생할 때 사 용되며, 청력손실로 인한 감정이나 부적응 행동을 다루는 도구 및 이완 등이 포함된다(Jang et al., 2018; Tye-Murray, 2009). 인지된 청 력손실은 적응 전략의 사용과 어느 정도 관련이 있다(Gomez \& Madey, 2001). 적응 전략의 예로는 청각장애들은 친숙하지 않은 사 람과 대화를 하게 될 경우 긴장하거나, 상대방이 못 알아들으면 어 쩌나, 또 자신을 어떻게 생각할 것인가를 걱정하는 것 등이 있다. 이 럴 경우에 숨을 깊게 들이마시고, 긴장을 풀며, 그들의 생각을 의식 적으로 현재의 대화와 환자의 입술 움직임에 더 집중하도록 한다. 이러한 적응 전략은 긴장을 이완시켜줄 뿐 아니라 대화를 잘 알아 들을 수 있도록 도움을 준다. 또한 의사소통 상호작용을 준비함에 있어 예기 전략을 사용할 수 있다(Jang et al., 2018; Tye-Murray, 2009). 예기 전략은 부족한 청각입력의 한계성을 극복하고 의사소 통을 성공적으로 사용하기 위해 예기되는 의사소통 상황을 문맥 과 틀에 맞춰 연습하는 전략이다(Suk, 2004). 예를 들면 난청인은 의사 진료와 같은 향후 의사소통 상호작용을 준비하여 발생할 수 있는 어휘와 문장을 고려할 수 있으며, 해당 항목을 말하는 파트너 의 말하기 읽기를 연습할 수 있다. 또한 예기 전략을 사용한다면, 의 사소통 상호작용 중에 말을 더 잘 읽고, 더 자신감 있고, 편안하게 느낄 것이다(Tye-Murray, 1992).
수정 전략(Repair strategy)은 의사소통의 실패를 겪어 신호를 수 정하거나 변경하여 의사소통을 유지하는 전략이며(Alexander, Wetherby, \& Prizant, 1997), 또한 대화 상대방에게 자신이 처한 어 려움을 타인에게 말하고 문제를 해결하기 위한 도움 요청 및 의미 타협 과정이다(Jin, 2000). 의사소통 단절(Communication breakdown)은 주어진 메시지를 청자가 이해하지 못해 상호간 혼란이 있 는 상태를 의미한다(Tye-Murray, 1994). 수정 전략은 수용적 수정 전략과 표현적 수정 전략이 있다. 수용적 수정 전략(Receptive repair strategy)은 난청인이 의사소통 파트너의 메시지를 이해하지 못 했을 때 사용하며, 반복 수정 전략, 정보요청 수정 전략, 정교화 수 정 전략이 있으며(Jang et al., 2018; Tye-Murray, 2009), 고쳐 말하기, 핵심단어 요구, 부분반복, 철자 요구, 글씨쓰기 요구 등이 있다(Suk, 2004). 표현적 수정 전략(Expressive repair strategy)은 환자가 말을 불명료하게 산출하여, 의사소통 파트너가 이해하지 못할 때 사용된 다. 예를 들면 말의 속도를 줄여 천천히 말하고 중요한 단어들만 강 조하기, 긴 문장을 나누어 이야기하기, 쓰기나 몸짓 등 다른 의사소 통 사용하기 등이 있다(Jang et al., 2018; Tye-Murray, 2009).

청능재활로 통해 난청인이 위에 언급한 의사소통 전략의 방법을 배운다면 난청인이 난청으로 인해 일상생활에서 부딪히는 어려움 을 극복하는데 상당한 도움이 될 수 있다. 건청인이나 난청인이 일상 생활에서 사용하는 의사소통 전략 유형을 파악하여 일상생활에 적 용하도록 도와주는 설문지의 개발은 이들의 의사소통 발전에 큰 도 움이 될 것이다. 난청과 관련된 다른 설문지들은 국내에서 개발되어 있지만, 국내에서 난청인의 의사소통 전략을 평가하기 위한 설문지 나 의사소통 전략을 개선하기 위한 다른 방법들의 개발이 미비한 실 정이다(Suk, 2004). 따라서 본 연구에서는 난청인의 의사소통 전략 과 의사소통 태도 척도를 평가할 수 있는 설문지로 Kaplan, Bally, Brandt, Busacco와 Pray (1997)가 개발한 노인의 의사소통척도 (Communication Scale for Older Adults, CSOA) 설문지를 국내 실 정에 맞게 수정하였고, 난청 유무에 따른 의사소통 전략 및 의사소 통 태도 척도 변화를 평가하여, 심층적인 정보를 제공하여 상담에 활용하고 보청기 착용효과를 극대화하도록 도와주는 한국어판 노 인의 의사소통척도(Korean version of Communication Scale for Older Adults, K-CSOA)의 타당도와 신뢰도를 조사하고자 한다.

\section{연구방법}

\section{연구대상}

본 연구의 모든 과정은 대학의 생명윤리위원회 심의를 받았으며 (CUIRB-2020-0067), 대상자의 동의에 따라 진행하였다. 대상자는 
Table 1. Distributions of subjects by the degree of hearing loss

\begin{tabular}{lc}
\hline Degree of hearing loss & \# of number \\
\hline Normal $(25 \mathrm{~dB}-)$ & 30 \\
Mild $(26-40 \mathrm{~dB})$ & 8 \\
Moderate $(41-55 \mathrm{~dB})$ & 14 \\
Moderate-severe $(56-70 \mathrm{~dB})$ & 3 \\
Severe $(71-90 \mathrm{~dB})$ & 5 \\
Profound $(91 \mathrm{~dB}+)$ & 0 \\
Total & 60 \\
\hline
\end{tabular}

대구, 경북, 부산에 위치한 보청기 센터, 이비인후과, 복지관, 요양원 의 방문자 대상으로 Kaplan 등(1997)의 이전 연구와 동일한 대상자 기준을 토대로 만 60 세에서 85 세의 보청기 착용 유무 상관없이, 난 청의 정도는 Table 1 에서와 같이 경도(Mild)에서 고도(Severe)의 양 측 감각신경성 난청(Sensorineural hearing loss) 또는 양측 혼합성 난청(Mixed hearing loss)을 가진 노인 30 명과 $25 \mathrm{~dB}$ 이내의 정상 청력을 가진 노인 30 명을 선정하여, 연구를 진행하였다. 난청군 및 대조군의 각 그룹의 평균 나이는 만 72 세이며, 대상자들 중 인지 및 신경학적 문제가 있는 자는 연구 대상자에서 제외하였다.

\section{연구절차}

본 연구의 절차는 Kaplan 등(1997)이 개발한 설문지를 한국어로 번역 후 영어 번역이 잘되었는지를 전문가 5 명에게 확인 후에 최종 적으로 번역을 완료하고, 기본정보 및 사례력 조사, 순음청력검사, 설문지 조사, 2주 후 설문지 재조사로 진행된다.

(1) 대상자 선정도구로 청력손실 정도를 평가하는 다양한 순음 역치평균을 측정한다. 보청기 센터의 방음실 및 조용한 방 안 에서 $0.5,1,2,4 \mathrm{kHz}$ 의 주파수마다 기도역치와 골도역치를 측 정하였다.

(2) 개발한 한국어판 노인의 의사소통척도(Korean version of Communication Scale for Older Adults, K-CSOA)의 타당도 와 신뢰도를 확인하기 위해 난청 노인과 정상 노인에게 한국 어판 노인의 의사소통척도 설문지를 사용한다. 대상자의 상 태에 따라 설문지 작성 시 대상자가 읽기와 기록이 가능한 경 우 대상자가 직접 읽고 기록하는 방식(Paper-Pencil)을 시행 하고, 대상자가 글을 모르거나, 읽지 못하거나, 내용을 이해하 기가 어렵다고 하는 경우 연구자가 질문을 읽어주고 대상자 가 대답을 하면 연구자가 기록하는 방식(Face to Face)으로 시 행하였다.

(3) 검사-재검사 신뢰도 확인을 위해 2 주 후 한국어판 노인의 의 사소통척도 재검사를 실시하였다.
(4) K-CSOA 의 타당도를 확인하기 위하여 구성타당도와 준거타 당도를 얻었고 신뢰도를 확인하기 위하여 내적일관성과 검 사-z'재검사 신뢰도를 얻었다. K-CSOA의 구성타당도는 K$\mathrm{CSOA}$ 의 총 점수와 의사소통 전략 및 태도의 하위 항목 간의 피어슨 상관계수(Pearson's Correlation Coefficeint)로 검증 되었다. $\mathrm{K}-\mathrm{CSOA}$ 의 준거타당도는 K-CSOA 의 전략 및 태도 척 도와 The Korean Hearing Handicap Inventory for the Elderly (KHHIE)의 피어슨 상관계수로 검증되었다. K-CSOA의 신 뢰도 검증에서는 크론바흐 알파계수(Chronbach Alpha Coefficeint)를 사용하여 내적일관성이 검증되었고 1차 K-CSOA 설문과 2 차 $\mathrm{K}-\mathrm{CSOA}$ 설문 간 피어슨 상관계수를 사용하여 검 사 및 재검사 신뢰도가 검증되었다.

\section{한국어판 노인의 의사소통척도}

본 연구에 사용된 한국어판 노인의 의사소통척도(Korean version of Communication Scale for Older Adults, K-CSOA)는 Kaplan 등(1997)이 개발한 노인의 의사소통척도(Communication Scale for Older Adults, $\mathrm{CSOA}$ )를 한국 실정에 맞게 번안한 것이다. 원래 $\mathrm{CSOA}$ 는 청능재활이 일상생활에 미치는 영향에 대한 심층적 정보를 얻기 위해 난청 노인의 의사소통척도를 평가하기 위한 설문 지로 대상자의 의사소통 전략(Communication strategies)과 대상 자의 의사소통 태도(Communication attitudes)를 평가한다. 의사 소통 전략 척도는 실제 또는 잠재적인 의사소통 단절(Communication breakdown), 특정 예기(Specific anticipatory), 각 상황에 적합 한 환경 전략(Environmental strategies) 및 수정 전략(Repair strategies)을 확인하지만 의사소통 전략에는 또한 알아들은 척하기 (Bluffing) 또는 회피행동(Avoidance behavior)과 같은 부적절한 전략도 평가에 포함되었다. 의사소통 태도 척도는 환자가 청력 간 손실에 대해 어떻게 느끼는지, 변화된 의사소통에 대한 조정 및 다 른 사람이 청력손실이 있는 대상자에게 어떻게 반응하는지에 대한 인식을 평가한다. 노인의 의사소통척도 항목의 형식은 Hearing Performance Inventory (Lamb, Owens, \& Schubert, 1983)와 Communication Profile for Hearing Impaired (Demorest \& Erdman, 1987)을 모델로 제작되었다.

노인의 의사소통척도는 총 72 개의 문항으로 구성되었고, 전체 중 의사소통 전략 척도는 41 문항과 의사소통 태도 척도는 31 문항 으로 구성되었다. 응답 형식은 3점 척도 (1) 항상 그렇다(Almost always), (2) 종종 그렇다(Sometimes), (3) 항상 그렇지 않다(Almost never)고 제시하거나, 5점 척도는 (1) 항상 그렇다(Always), (2) 대부 분 그렇다(Almost always), (3) 종종 그렇다(Sometimes), (4) 거의 그 
렇지 않다(Almost never), (5) 항상 그렇지 않다(Never)로 제시한 다. 노인을 위해 제작된 대부분의 형식는 3 점 척도 혹은 더 간단한 척도이지만, 데이터 수집 과정에서 대답 형식에 더 많은 선택을 지 속 요청하여, 5점 척도가 개발되었다. 검사자는 필요에 따라 두 척 도 중 하나를 사용할 수 있다. 또한 의사소통 전략 척도와 의사소통 태도 척도는 서로 독립적으로 사용이 가능하지만, 의사소통 전략 척도와 의사소통 태도 척도 모두에서 높은 점수는 의사소통의 어 려움을 나타낸다. 의사소통 태도 척도에서는 청력손실로 인한 자 신의 태도, 가족의 대한 태도, 가족 외 다른 사람의 태도에 대한 인 식도 평가가 되었다.

의사소통 전략 척도 항목에서 1 번에 대한 응답은 어려움이 거의 없음을 나타낸다. 그러나 특정 부적절한 전략 항목에서는 역점수 로 변환하여 점수를 모든 문항의 점수를 더해서 평균을 구해서 계 산한다. 역점수가 필요한 항목은 Appendix 1 (설문지에 ^로 표시 됨)에 표시되어 있다. 의사소통 태도 척도도 마찬가지로 동일한 절 차로 채점을 실시하였다. 척도의 평균 점수가 낮아지는 것은 의사 소통 전략을 더 좋게 사용하는 것이며, 청력손실에 대한 태도 개선 등을 취할 수 있다. 의사소통 전략 및 의사소통 태도 척도에서 .10 이상 차이 점수는 개선을 보인 것으로 간주할 수 있다. 반면에 -.10 이하 차이는 악화를 나타낸다. 의사소통 전략 및 태도 척도는 치료 나 재활에서 목표로 삼을 영역을 식별하고, 강점과 약점에 대한 상 담을 위해 난청인에 대한 기본 데이터를 얻는데 사용할 수 있다 (Kaplan et al., 1997). 그러나 Kaplan 등(1997)의 연구에서 CSOA의 신뢰도 검사는 하였지만, 타당도를 검증하지 않은 단점이 있다.

따라서 본 연구에서는 한국어로 번역한 후 전문가 5 명에게 검토 를 받은 후 설문지에 사용된 용어와 내용의 적절성을 고려하여 번
역된 후, 설문지 번역의 과정에서 설문지의 각 문장을 “합니다.”에 서 “한다.” 로 통일하였고 ‘I’ 또는'You'와 같은 1 인칭 또는 2인칭 문 장은 번역 과정 중에 어감을 부드럽게 하기 위하여 생략하였지만 문장의 내용 상 생략이 불가능한 경우에는 그대로 유지하였다. 문 장을 한국의 정서, 문화, 및 상황에 적절하고 연구 참여자들이 이해 하기 쉬운 단어를 선정하여 최종 번안하였다. 설문지 최종 번안본 은 Appendix 1에 표기해두었다. 의사소통 전략 척도는 촉진 전략, 수정 전략, 예비 전략으로 구성되었고, 촉진 전략에는 적응 전략, 구 조 전략, 지시 전략, 예기 전략, 메시지 구성 전략이 포함되었으며, 수 정 전략 항목에는 반복, 부분반복, 목표단어, 글씨쓰기 요구, 철자 요구 항목들이 포함되었다. 마지막으로 예비 전략에는 유지 전략 (대화시작하기), 유지 전략(차례지키기), 부적응 전략이 포함된다 (Table 2). 이러한 의사소통 전략 척도를 이용하여 국내 난청인의 의 사소통 전략 및 의사소통의 어려움에 대해 알아볼 수 있을 것이다.

의사소통 태도 척도는 본인의 태도, 가족의 태도, 타인의 태도로 구성되었고, 본인의 태도 항목에서만 세부항목을 수치(Shame), 분

Table 3. Subcategories of communication attitudes

\begin{tabular}{llcc}
\hline Subcategories & Items & Item numbers & \# of item \\
\hline Own attitude & Shame & $1,4,5,11,18$ & 5 \\
& Anger & $2,3,7,9,10,12,17$ & 7 \\
& Accept & $13,19,20,24,25$ & 5 \\
& Tension & 14 & 1 \\
& Depression & 15 & 1 \\
Family's attitude & & $8,16,21,23,27,28,30$ & 7 \\
Others attitude & & $6,22,26,29,31$ & 5 \\
Total & & 31 \\
\hline
\end{tabular}

Table 2. Subcategories of communication strategies

\begin{tabular}{|c|c|c|c|}
\hline Subcategories & Items & Item numbers & \# of item \\
\hline \multirow[t]{5}{*}{ Facilitative strategies } & Adaptive strategy & 15 & 1 \\
\hline & Constructive strategy & 11,14 & 2 \\
\hline & Instructional strategy & $16,17,18,19,23,27,30,34,40$ & 9 \\
\hline & Anticipatory strategy & 21,22 & 2 \\
\hline & Message-tailoring strategy & 25 & 1 \\
\hline \multirow[t]{5}{*}{ Repair strategies } & Repeat & 1 & 1 \\
\hline & Repeat part & 3,5 & 2 \\
\hline & Keywords & 10,29 & 2 \\
\hline & Require write & $4,12,20$ & 3 \\
\hline & Require spelling & 6,8 & 2 \\
\hline \multirow[t]{3}{*}{ Preparatory strategies } & Before conversation start & 28 & 1 \\
\hline & Turn taking & 39 & 1 \\
\hline & Maladaptive strategy & $2,7,9,13,24,26,31,32,33,35,36,37,38,41$ & 14 \\
\hline Total & & & 41 \\
\hline
\end{tabular}


노(Anger), 수용(Accept), 긴장(Tension), 우울(Depression)로 구성 되었다(Table 3). 이러한 의사소통 태도 척도를 이용하여 국내 난청 인의 의사소통 태도 및 의사소통의 어려움에 대해 알아볼 수 있을 것이며, 점수를 계산하는 것은 Kaplan 등(1997)의 이전 연구와 동 일하게 총 문항의 합을 더해 총 평균 점수 값을 구하여 계산을 하는 데 특정 문항에서 점수를 역변환하여, 점수 값을 계산하였다. 역변 환 문항은 Kaplan 등(1997)의 이전 연구와 동일하며, Appendix 1에 있는 K-CSOA 설문지 안에 문항번호 옆 *모양으로 표시해뒸다.

\section{통계분석}

자료 통계처리는 IBM SPSS (Statistic Packages for Social Science, IBM, Inc., USA) Version 26.0을 사용하였다. K-CSOA 구성 타당도를 확인하기 위해서 총 점수와 의사소통 전략 및 태도의 하 위 항목의 상관관계를 확인하고, 항목 간 상관관계를 확인하기 위 해서 피어슨 상관계수(Pearson's Correlation Coefficeint)를 사용 하였다. K-CSOA의 신뢰도 검증을 위해서 내적일관성 확인을 위해 크론바흐 알파계수(Chronbach Alpha Coefficeint)를 사용하였다. 검사 및 재검사 신뢰도를 위해서는 1 차 K-CSOA 설문과 2 차 K$\mathrm{CSOA}$ 설문 간 피어슨 상관계수를 사용하였다. $\mathrm{K}-\mathrm{CSOA}$ 의 준거타 당도를 확인하기 위해서 $\mathrm{K}-\mathrm{CSOA}$ 의 전략 척도와 태도 척도와 $\mathrm{HHIE}$ 의 상관관계를 확인하기 위해 피어슨 상관계수를 사용하였 다. K-CSOA의 임상적 타당도를 확인하기 위해서는 난청 노인과 정 상 노인을 나누어 총 평균 점수 차이를 보기 위해 Independent $t$ test 실시하였다.

\section{연구결과}

\section{$\mathrm{K}-\mathrm{CSOA}$ 의사소통 전략 척도의 구성타탕도}

$\mathrm{K}-\mathrm{CSOA}$ 의사소통 전략 척도의 구성타당도를 확인하기 위해서 난청군 및 대조군의 K-CSOA 검사 결과를 사용하였으며, 총 60 명 의 검사를 분석하였다. 의사소통 전략 척도의 구성타당도를 분석 하기 위해서 피어슨 상관계수를 사용하였다(Table 4). 의사소통 전 략총 평균 점수와촉진 전략항목 점수는 매우 높은 상관관계를 보

Table 4. Construct validity of K-CSOA

\begin{tabular}{lcccc}
\hline & Total & Facilitative & Repair & Preparatory \\
\hline Total & 1 & & & \\
Facilitative & $.936^{* * *}$ & 1 & & \\
Repair & $.902^{* * *}$ & $.807^{* * *}$ & 1 & \\
Preparatory & $.818^{* * *}$ & $.608^{* * *}$ & $.602^{* * *}$ & 1 \\
\hline
\end{tabular}

${ }^{* * *} p<.001$.
였으며 $(r=.936, p<.001)$, 의사소통 전략 총 평균 점수와 수정 전략 의 점수도 매우 높은 양의 상관관계를 보였다 $(r=.902, p<.001)$. 마 지막으로 의사소통 전략 총 평균 점수와 예비전략 항목의 점수도 매우 높은 양의 상관관계를 보였다 $(r=.818, p<.001)$.

의사소통 전략 척도의 항목 간 상관관계를 분석하기 위해서 피 어슨 상관계수를 사용하였다(Table 4). 촉진 전략과 수정 전략 항 목의 상관관계를 확인하였을 때 이 둘은 매우 높은 양의 상관관계 를 보였으며 $(r=.807, p<.001)$, 수정 전략과 예비 전략 항목의 평균 점수는 중간 정도의 양의 상관관계를 보였다 $(r=.602, p<.001)$. 촉 진 전략과 예비 전략 항목의 평균은 중간 정도의 양의 상관관계를 보였다 $(r=.608, p<.001)$.

\section{K-CSOA 의사소통 태도 척도의 구성타당도}

$\mathrm{K}-\mathrm{CSOA}$ 의사소통 태도 척도의 구성타당도를 확인하기 위해서 난청군 및 대조군의 K-CSOA 검사 결과를 사용하였으며, 총 60 명 의 검사를 분석하였다. 의사소통 태도 척도의 구성타당도를 분석 하기 위해서 피어슨 상관계수를 사용하였다(Table 5). 의사소통 태 도 총 평균 점수와 본인의 태도 항목의 점수는 매우 높은 양의 상관 관계를 보였으며 $(r=.984, p<.001)$, 의사소통 태도 총 평균 점수와 가족의 태도 항목의 평균 점수는 중간 정도 양의 상관관계를 보였 다 $(r=.623, p<.001)$. 의사소통 태도 총 평균 점수와 타인의 태도 항 목의 평균 점수는 높은 양의 상관관계를 보였다 $(r=.779, p<.001)$. 의사소통 태도 척도의 항목 간 상관관계를 분석하기 위해서 피어 슨 상관계수를 사용하였다. 본인의 태도와 가족의 태도 항목은 중 간 정도 양의 상관관계를 보였으며 $(r=.502, p<.001)$, 본인의 태도 와 타인의 태도 항목의 평균 점수 상관관계는 높은 양의 상관관계 를 보였다 $(r=.697, p<.001)$. 가족의 태도와 타인의 태도 항목의 평 균 점수의 상관관계는 중간 정도 양의 상관관계를 보였다 $(r=.506$, $p<.001)$.

\section{$\mathrm{K}-\mathrm{CSOA}$ 의사소통 전략 척도의 신뢰도 \\ $\mathrm{K}-\mathrm{CSOA}$ 의사소통 전략 척도 내적일관성}

$\mathrm{K}-\mathrm{CSOA}$ 의사소통 전략 척도의 내적일관성을 확인하기 위해서

Table 5. Construct validity of communication attitudes scale

\begin{tabular}{lcccc}
\hline & Total & Own attitude & Family's attitude & Others attitude \\
\hline Total & 1 & & & \\
Own attitude & $.984^{* * *}$ & 1 & 1 & 1 \\
Family's attitude & $.623^{* * *}$ & $.502^{* * *}$ & $.506^{* * *}$ & 1 \\
Others attitude & $.779^{* * *}$ & $697^{* * *}$ &
\end{tabular}


총 60 명의 검사를 분석하였다(Table 6). 의사소통 전략 척도의 내적 일관성을 확인하기 위해서 크론바흐 알파계수를 사용하여 분석하 였다. 의사소통 전략 척도 총 평균과 촉진전략 15 항목의 내적일관 성을 확인한 결도 매우 높은 일관성을 보였으며 $(\alpha=.802)$, 의사소 통 전략 척도 총 평균과 수정 전략 10 항목의 내적일관성을 확인한 결과도 매우 높은 일관성을 보였다 $(\alpha=.889)$. 마지막으로 의사소통 전략 척도 총 평균과 예비 전략 16 항목의 내적일관성을 확인하였 을 때도 매우 높은 일관성을 보였다 $(\alpha=.930)$.

\section{의사소통 전략 척도의 검사-재검사 신뢰도}

$\mathrm{K}-\mathrm{CSOA}$ 의사소통 전략 척도의 검사-재검사 신뢰도를 확인하기 위해서 총 60 명의 검사를 분석하였다. 1 차 K-COSA 의사소통 전략 척도 검사로부터 2주 후 2차 K-CSOA를 실시하였으며, 검사-재검사 신뢰도를 확인하기 위해서 피어슨 상관계수를 사용한 결과 Table 7 에서와 같이 높은 검사-재검사 신뢰도를 보였다 $(r=.986, p<.001)$.

\section{K-CSOA 의사소통 태도 척도의 신뢰도}

\section{의사소통 태도 척도 내적일관성}

$\mathrm{K}-\mathrm{CSOA}$ 의사소통 태도 척도의 내적일관성을 확인하기 위해서 총 60 명의 검사를 분석하였다(Table 8). 의사소통 태도 척도의 내적 일관성을 확인하기 위해서 크론바흐 알파계수를 사용하여 분석하

Table 6. Internal consistency of communication strategies scale

\begin{tabular}{lcc}
\hline Subcategory & Cronbach`s Alpha & Item \\
\hline Communication strategies & & \\
Facilitative & .802 & 15 \\
Repair & .889 & 10 \\
Preparatory & .930 & 16 \\
Total & & 41 \\
\hline
\end{tabular}

Table 7. Test-retest correlation of communication strategies

\begin{tabular}{lcc}
\hline & Test & Retest \\
\hline Test & 1 & \\
Retest & $.986^{* * *}$ & 1 \\
\hline
\end{tabular}

${ }^{* * *} p<.001$.

Table 8. Internal consistency of communication attitudes

\begin{tabular}{lcc}
\hline Subcategory & Cronbach`s Alpha & Item \\
\hline Communication attitudes & & \\
Own & .962 & 19 \\
Family & .620 & 7 \\
Others & .710 & 5 \\
Total & & 31 \\
\hline
\end{tabular}

였으며, 의사소통 태도 척도 총 평균과 본인의 태도 19항목의 내적 일관성을 확인한 결과 매우 높은 일관성을 보였으며 $(\alpha=.962)$, 의사 소통 전략 척도 총 평균과 가족의 태도 7항목의 내적일관성을 확인 한 결과는 중간 정도의 일관성을 보였다 $(\alpha=.620)$. 마지막으로 의 사소통 전략 척도 총 평균과 타인의 태도 5 항목의 내적일관성을 확 인하였을 때는 높은 일관성을 보였다 $(\alpha=.710)$.

의사소통 태도 척도의 검사-재검사 신뢰도

$\mathrm{K}-\mathrm{CSOA}$ 의사소통 태도 척도의 검사-재검사 신뢰도를 확인하기 위해서 총 60 명의 검사를 분석하였다. 1 차 K-COSA 의사소통 태도 척도 검사로부터 2주 후 2차 K-CSOA를 실시하였으며, 검사-재검 사 신뢰도를 확인하기 위해서 피어슨 상관계수를 사용한 결과 Table 9 에서와 같이 높은 검사-재검사 신뢰도를 보였다 $(r=.988$, $p<.001)$.

\section{$\mathrm{K}-\mathrm{CSOA}$ 의 준거타당도}

의사소통 전략 척도와 한국 노인성 난청의 청각장애지수(The Korean Hearing Handicap Inventory for the Elderly, $\mathrm{KHHIE})$ 의 상관관계

$\mathrm{K}-\mathrm{CSOA}$ 의사소통 전략 척도와 한국 노인성 난청의 청각장애지 수(The Korean Hearing Handicap Inventory for the Elderly, KH$\mathrm{HIE})$ 의 상관관계를 확인하기 위해서 K-CSOA와 KHHIE 검사를

Table 9. Test-retest correlation of communication attitudes

\begin{tabular}{lcc}
\hline & Test & Retest \\
\hline Test & 1 & \\
Retest & $.988^{* * *}$ & 1 \\
\hline$* * * p<.001$. & &
\end{tabular}

Table 10. Correlation between Communication Strategies of K-CSOA and KHHIE

\begin{tabular}{lcc}
\hline & Communication strategies & KHHIE \\
\hline Communication strategies & 1 & \\
KHHIE & $.784^{* * *}$ & 1 \\
\hline
\end{tabular}

${ }^{* * *} p<.001$.

Table 11. Correlation between communication attitudes of K-CSOA and $\mathrm{KH}$ HIE

\begin{tabular}{lcc}
\hline & Communication attitudes & KHHIE \\
\hline Communication attitudes & 1 & \\
KHHIE & $.823^{* * *}$ & 1 \\
\hline$* * * p<.001$. &
\end{tabular}


시행한 총 60 명의 검사를 분석하였다. 두 검사 점수의 상관관계를 분석하기 위해서 피어슨 상관계수를 사용한 결과 Table 10에서와 같이 높은 양의 상관관계를 보였다 $(r=.784, p<.001)$.

\section{의사소통 태도 척도와 한국 노인성 난청의 청각장애지수(The}

Korean Hearing Handicap Inventory for the Elderly, KHHIE)의 상관관계

$\mathrm{K}-\mathrm{CSOA}$ 의사소통 태도 척도와 한국 노인성 난청의 청각장애지 수(The Korean Hearing Handicap Inventory for the Elderly, KH$\mathrm{HIE})$ 의 상관관계를 확인하기 위해서 K-CSOA와 KHHIE 검사를 시행한 총 60 명의 검사를 분석하였다. 두 검사 점수의 상관관계를 분석하기 위해서 피어슨 상관계수를 사용한 결과 Table 11에서와

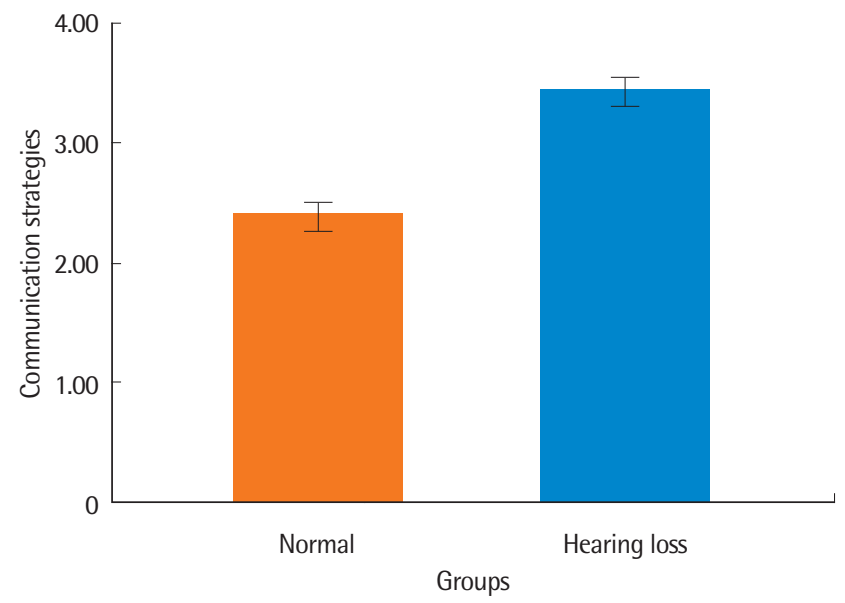

Figure 1. Comparison of communication strategies between normal and hearing loss groups.

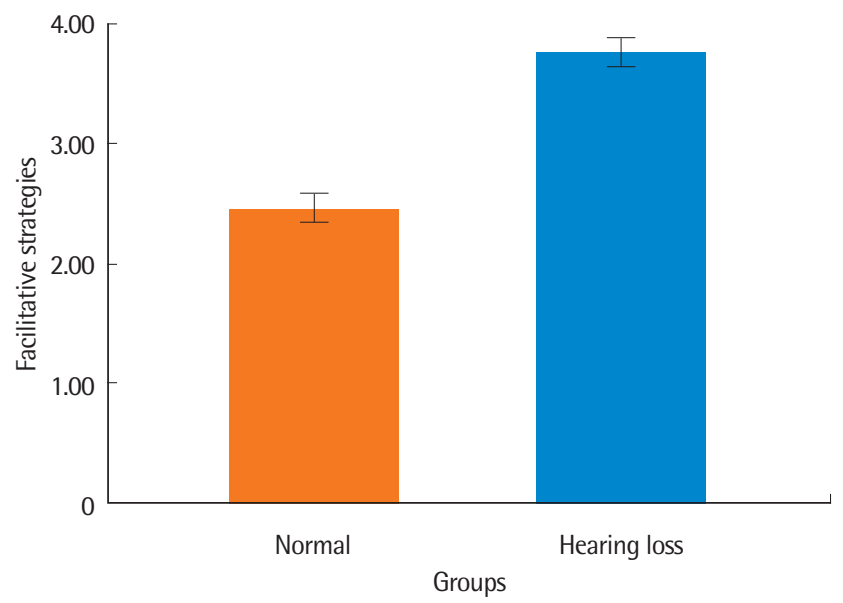

Figure 2. Comparison of facilitative strategies between normal and hearing loss groups.
같이 높은 양의 상관관계를 보였다 $(r=.823, p<.001)$.

난청군과 대조군의 한국어판 노인의 의사소통척도( $\mathrm{K}-\mathrm{CSOA})$ 의 의사소통 전략의 총 평균 점수 차이 비교

$\mathrm{K}-\mathrm{CSOA}$ 의 의사소통 전략 평균 점수에서 정상군의 점수는 2.40 ( \pm .243$)$ 이고 난청군의 점수는 3.45 ( \pm .253$)$ 이었다. 정상 노인 집단 과 난청 노인 집단 간 $\mathrm{K}-\mathrm{CSOA}$ 의사소통 전략 척도 평균을 비교하 기 위해서 독립표본 $t$ 검정을 실시한 결과 Figure 1에서와 같이 두 집단 간 통계적으로 유의한 차이를 보였다 $(t(58)=-16.23, p<.001)$. 또한 Figure 2에서와 같이 촉진 전략은 두 집단 간 차이가 통계적으 로 유의하였으며 $(t(58)=-12.39, p<.001)$, Figure 3에서와 같이 수정 전략도 두 집단 간 차이가 통계적으로 유의하였다 $(t(58)=-9.673$,

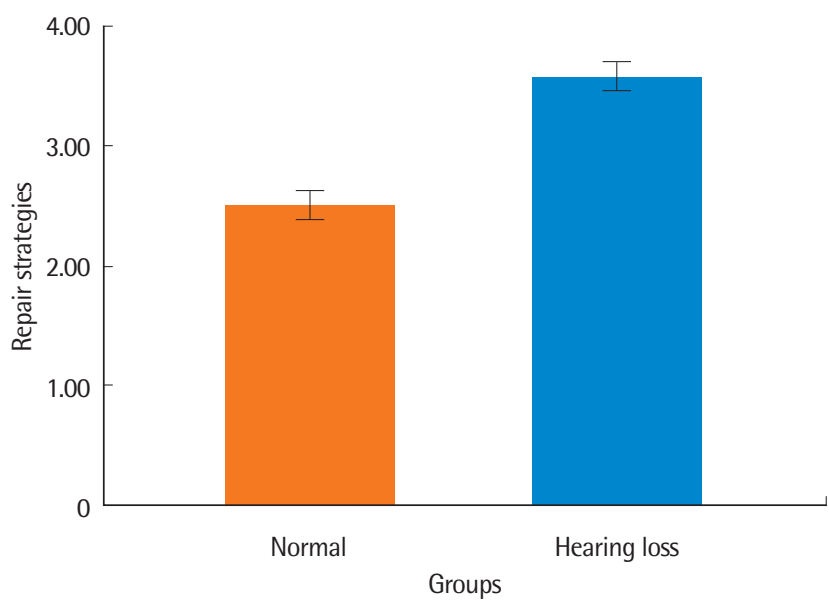

Figure 3. Comparison of repair strategies between normal and hearing loss groups.

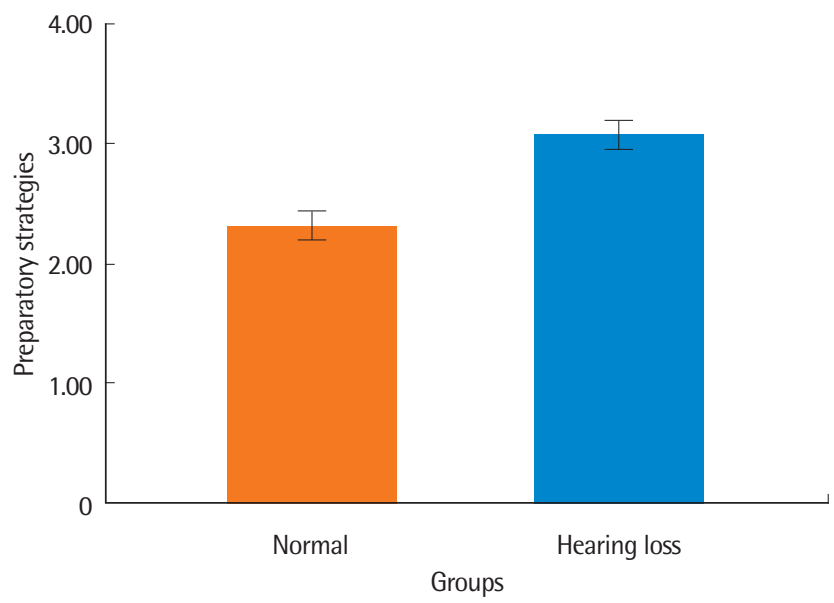

Figure 4. Comparison of preparatory strategies between normal and hearing loss groups. 


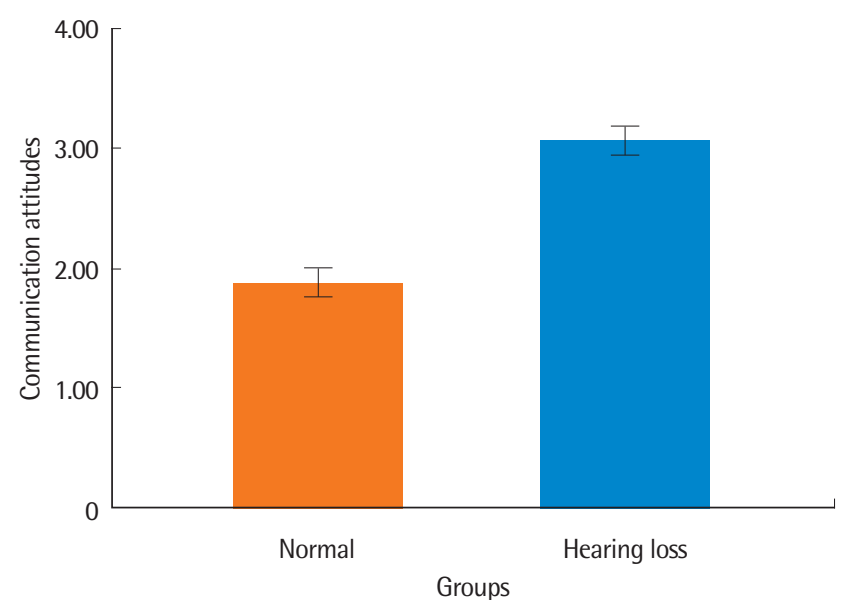

Figure 5. Comparison of Communication attitudes between normal and hearing loss groups.

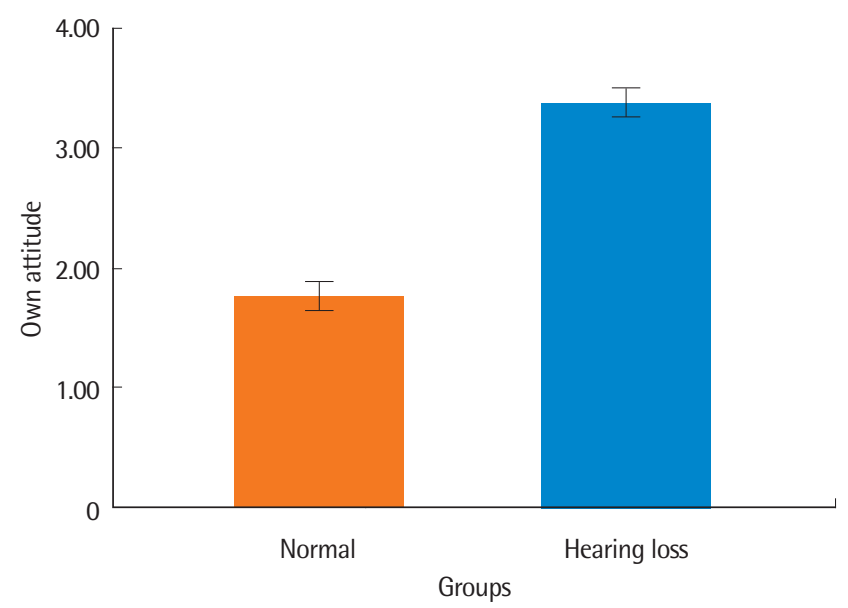

Figure 6. Comparison of own attitudes between normal and hearing loss groups.

$p<.001)$. 마지막으로 Figure 4에서와 같이 예비 전략에서도 두 집 단 간 차이가 통계적으로 유의하였다 $(t(58)=-8.919, p<.001)$.

\section{난청군과 대조군의 한국어판 노인의 의사소통척도( $\mathrm{K}-\mathrm{CSOA})$ 의 의사소통 태도의 총 평균 점수 차이 비교}

$\mathrm{K}-\mathrm{CSOA}$ 의 의사소통 태도 평균 점수에서 정상군의 점수는 1.88 ( \pm .273$)$ 이고, 난청군의 점수는 3.07 ( \pm .332$)$ 이었다. 정상 노인 집단 과 난청 노인 집단 간 K-CSOA 의사소통 태도 척도 평균을 비교하 기 위해서 독립표본 $t$ 검정을 실시한 결과 Figure 5 에서와 같이 두 집단 간 통계적으로 유의한 차이를 보였다 $(t(58)=-16.23, p<.001)$. 또한 Figure 6에서와 같이, 본인의 태도는 두 집단 간 차이가 통계적 으로 유의하였으며 $(t(58)=-16.70, p<.001)$, Figure 7에서와 같이, 가족의 태도에서는 두 집단 차이가 통계적으로 유의하였다 $(t(58)=$

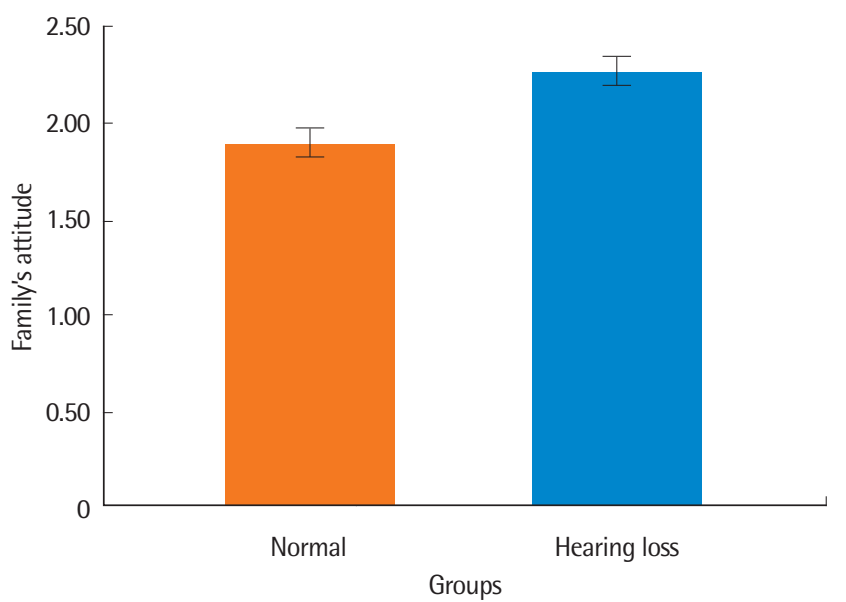

Figure 7. Comparison of family's attitudes between normal and hearing loss groups.

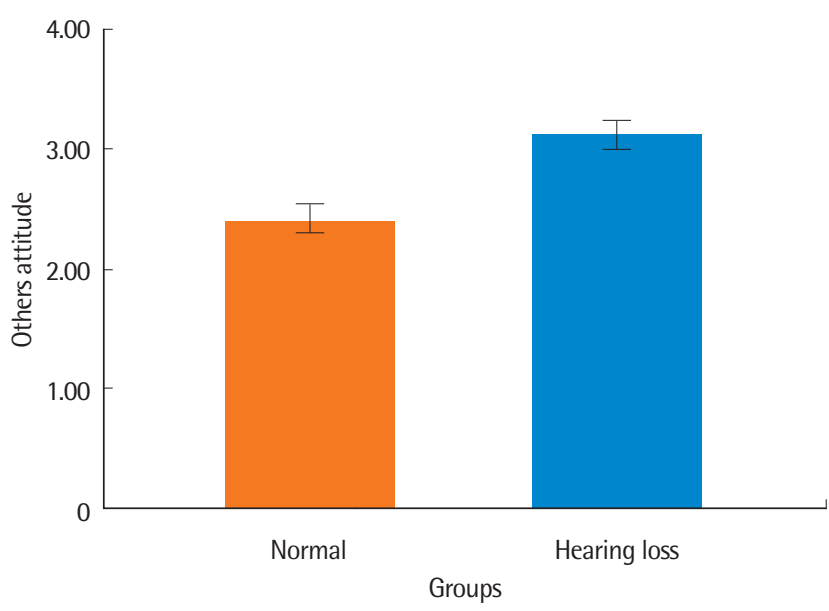

Figure 8. Comparison of others attitudes between normal and hearing loss groups.

-3.643,p <.001). 마지막으로 Figure 8에서와 같이, 타인의 태도에서 도 두 집단간차이가 통계적으로 유의하였다 $(t(58)=-6.406, p=0.00)$.

\section{논의 및 결론}

본 연구는 난청인의 의사소통 전략 및 태도 척도를 평가하는 도 구로 Kaplan 등(1997)이 개발한 노인의 의사소통척도(Communication Scale for Older Adults, CSOA)를 한국어로 번안하였다. 청 능재활의 프로그램 구성요소에는 보청기 적합, 청능훈련, 독화, 의 사소통 전략 등이 포함되어야 한다. 그러나 현재 국내에는 의사소 통 전략훈련이 제대로 이루어지지 않고 있으며, 난청 노인이 개인에 게 부족한 의사소통 전략을 훈련하기 위해서는 난청인이 어떠한 전 략을 잘 사용하고, 잘 사용하지 못하는지 평가하는 도구조차 전무 
한 실정이다. 그러하여 한국어판 노인의 의사소통척도(Korean version of Communication Scale for Older Adults, K-CSOA) 항목 간 타당도와 신뢰도를 검증하였고, K-CSOA와 국내에 번안된 난청 인의 청각장애지수 KHHIE를 비교하여 타당도를 검증하고, 난청 인의 의사소통 전략 및 태도를 반영할 수 있는 주관적 평가 설문지 를 임상에서 활용하여, 대상자에게 맞는 청능재활을 실시하기 위 한 심층적 상담에 활용할 수 있도록 하고자 하였다.

\section{$\mathrm{K}-\mathrm{CSOA}$ 의사소통 전략 척도의 구성타당도}

본 연구에서 $\mathrm{K}-\mathrm{CSOA}$ 의사소통 전략 척도의 구성타당도를 검정 하기 위해서 $\mathrm{K}-\mathrm{CSOA}$ 의사소통 전략 척도 총 평균 점수와 의사소 통 전략 척도 항목인 촉진 전략, 수정 전략, 예비 전략 항목의 점수 를 비교하였으며, 의사소통 전략 척도 항목 간 점수도 비교 분석하 였다. 결과적으로 총 평균 점수와 하위 항목 간 점수가 매우 높은 상관관계를 보였으며 촉진 전략, 수정 전략, 예비 전략 항목 순으로 높은 상관관계를 보였다. 의사소통 전략 척도 항목 간 점수에서는 촉진 전략과 수정 전략은 높은 상관관계를 보였으며, 촉진 전략과 예비 전략, 수정 전략과 예비 전략은 중간 정도의 상관관계를 보였 다. 따라서, K-CSOA 의사소통 전략 척도의 구성타당도는 상당히 우수한 것으로 확인되었다.

\section{K-CSOA 의사소통 태도 척도의 구성타당도}

본 연구에서 K-CSOA 의사소통 태도 척도의 구성타당도를 검정 하기 위해서 K-CSOA 의사소통 태도 척도 총 평균 점수와 의사소 통 태도 척도 항목인 본인의 태도, 가족의 태도, 타인의 태도 항목 의 점수를 비교하였으며, 의사소통 태도 척도 항목 간 점수도 비교 분석하였다. 결과적으로 총 평균 점수와 본인의 태도, 총 점수와 타 인의 태도 항목에서는 높은 상관관계를 보였으며, 총 평균 점수와 본인의 태도는 중간 정도의 양의 상관관계를 보였다. 총 평균 점수 와 본인의 태도, 총 평균 점수와 타인의 태도, 총 평균 점수와 가족 의 태도 항목 순으로 높은 상관관계를 보였다. 하위 항목 간 점수에 서는 본인의 태도와 타인의 태도 항목이 높은 상관관계를 보였으며 본인의 태도와 가족의 태도, 가족의 태도와 타인의 태도는 중간 정 도의 양의 상관관계를 보였다. 따라서, $\mathrm{K}-\mathrm{CSOA}$ 의사소통 태도 척 도의 구성타당도는 상당히 우수한 것으로 확인되었다.

\section{$\mathrm{K}-\mathrm{CSOA}$ 의사소통 전략 척도의 신뢰도}

본 연구는 K-CSOA 의사소통 전략 척도 신뢰도를 분석하기 위 해서 내적일관성과 검사-재검사 신뢰도를 확인하였다. 의사소통 전략 척도 내 항목 간 내적일관성을 확인하기 위해서 크론바흐 알
파계수(Cronbach's Alpha Coefficient)로 확인을 한 결과 값이 모 든 항목 간 알파 값이 .800 이상으로 매우 높은 일관성을 보였다. 총 평균 점수와 예비 전략 항목, 총 평균 점수와 수정 전략 항목, 총 평 균 점수와 촉진 전략 항목 순으로 높은 내적일관성을 보였다. 또한 검사-재검사 신뢰도를 확인하기 위해서 피어슨 상관계수(Pearson's Correlation Coefficient)를 사용하여 결과가 .986으로 매우 높은 상관관계를 보였다. 따라서, $\mathrm{K}-\mathrm{CSOA}$ 의사소통 전략 척도는 주관적 인 평가임에도 불구하고, 연구에 참여한 난청군 및 대조군 60 명 모 두를 검사-재검사를 실시하였을 때, 피어슨 상관계수가 높게 나타 났으므로, 이러한 결과는 K-CSOA 의사소통 전략 척도가 높은 신 뢰도를 보이는 평가도구임을 시사할 수 있다.

\section{$\mathrm{K}-\mathrm{CSOA}$ 의사소통 태도 척도의 신뢰도}

본 연구는 K-CSOA 의사소통 태도 척도 신뢰도를 분석하기 위 해서 내적일관성과 검사-재검사 신뢰도를 확인하였다. 의사소통 태도 척도 내 항목 간 내적일관성을 확인하기 위해서 크론바흐 알 파계수로 확인을 한 결과 값이 본인의 태도 알파 값이 .962로 매우 높은 일관성을 보였고, 가족의 태도 알파 값은 .620으로 중간 정도 의 일관성, 타인의 태도 알파 값은 .710으로 높은 일관성을 보였다. 또한 검사-재검사 신뢰도를 확인하기 위해서 피어슨 상관계수를 사용하여 결과가 .988로 매우 높은 상관관계를 보였다. 따라서, K$\mathrm{CSOA}$ 의사소통 태도 척도는 주관적인 평가임에도 불구하고, 연구 에 참여한 난청군 및 대조군 60 명 모두를 검사-재검사를 실시하였 을 때, 피어슨 상관계수가 높게 나타났으므로, 이러한 결과는 K$\mathrm{CSOA}$ 태도 척도가 높은 신뢰도를 보이는 평가 도구임을 시사할 수 있다.

\section{K-CSOA 의사소통 전략 및 태도 척도의 준거타당도}

$\mathrm{K}-\mathrm{CSOA}$ 의 준거타당도를 측정하기 위해서 난청인의 청각장애 지수를 평가하는 기존 설문지들 중 하나인 KHHIE와 비교하여 준 거타당도를 검증하였다. KHHIE는 Khoo와 Kim (2000)의 연구에 서 타당도와 신뢰도가 검증되었으며, 난청인의 사회/상황적 측면과 심리적인 측면을 고려한 재활, 보청기 착용 효과, 다양한 정보들을 세부적으로 측정할 수 있는 설문지이다. 본 연구에서는 K-CSOA 의사소통 전략 척도, 의사소통 태도 척도 점수와 KHHIE 간의 상 관관계를 알아보고자 피어슨 상관계수를 사용하였다. 의사소통 전 략 척도와 KHHIE의 상관관계는 .784이며, 의사소통 태도 척도와 KHHIE의 상관관계는 .823으로 나타났다. 두 척도와 KHHIE 상관 관계는 모두 높은 수준의 유의미한 양의 상관관계를 보였으며, 검 사 모두 난청인을 평가하는 도구이지만, 검사 방식 및 해석 방법은 
다르므로 임상에서 난청인의 보청기 착용 전후 및 청능훈련 후 활 용하면 대상자의 주관적인 문제 및 심층적인 상담에 활용할 수 있 을 것이라 사료된다.

\section{$\mathrm{K}-\mathrm{CSOA}$ 의 의사소통 전략 및 태도 점수 집단 간 차이}

$\mathrm{K}-\mathrm{CSOA}$ 의사소통 전략 척도의 총 평균 점수가 정상군과 난청 군 간 유의미한 차이를 나타냈다. 정상군의 의사소통 전략 척도의 총 평균 점수는 2.40 이며, 표준편차는 .243으로 나타났고, 난청군 의 의사소통 전략 총 평균 점수는 3.45 이며, 표준편차는 .253으로 나타났다. 두 집단 간의 총 평균점수 차이는 1.05 로 나타났으며, 난 청군의 의사소통 전략 총 평균 점수는 정상군의 의사소통 전략 총 평균 점수와 비교하였을 때 유의미한 차이로 높은 총 평균점수를 보였다. K-CSOA 의사소통 전략 척도는 이전 연구인 Kaplan 등 (1997)에 의하면 총 평균 점수가 높을수록 의사소통 전략 및 의사 소통 사용의 어려움 및 문제를 보이는 것이라 해석할 수 있다. 의사 소통 전략 총 평균 점수뿐만 아니라 하위 영역인 수정 전략, 촉진 전 략 및 예비 전략에서도 난청군과 정상군 간 유의미한 차이를 보였 다. 또한 $\mathrm{K}-\mathrm{CSOA}$ 의사소통 태도 척도에서도 총 평균 점수가 난청 군과 정상군 간 유의미한 차이를 나타냈다. 정상군의 의사소통 태 도 척도 총 평균 점수는 1.88 이며, 표준편차는 .273 으로 나타났고, 난청군의 의사소통 태도 척도 총 평균 점수는 3.08 이며, 표준편차 는 332 으로 나타났다. 두 집단 간의 의사소통 태도 총 평균 점수차 이는 1.20 로 나타났으며, 난청군의 의사소통 태도 총 평균 점수는 정상군 총 평균 점수와 비교하였을 때 유의미한 차이로 총 높은 평 균점수를 보였다. K-CSOA 의사소통 태도 척도는 이전 연구 Kaplan 등(1997)에 의하면 총 평균 점수가 높을수록 의사소통 태도 및 의사소통 사용에 문제가 있는 것이라 해석할 수 있다. 총 평균 점 수뿐만 아니라 하위 영역인 본인의 태도, 가족의 태도, 타인의 태도 에서도 난청군과 정상군 간 유의미한 차이를 보였다. 이로써 한국 어판 노인의 의사소통척도가 난청 노인의 의사소통 전략 및 태도 수준을 평가할 수 있는 도구임을 시사한다.

\section{$\mathrm{K}-\mathrm{CSOA}$ 의 임상적 의미 및 한계}

본 연구에서 개발된 한국어판 노인의 의사소통척도(Korean version of Communication Scale for Older Adults, K-CSOA)는 높은 타당도와 신뢰도를 보여주었고 정상 청력의 노인과 난청 노인의 의 사소통의 전략과 태도를 평가할 수 있는 임상적으로 유용한 검사 도구임을 보여주었다. K-CSOA는 고령화 사회에 진입한 한국의 사 회에서 노인의 의사소통의 전략과 태도를 검사할 수 있는 유일한 검사도구로서 임상적으로 활용의 가치가 상당히 있을 것으로 고려
된다. 더불어 $\mathrm{K}-\mathrm{CSOA}$ 는 난청이 의사소통의 전략과 태도에 미치는 효과를 양화할 수 있고 난청인이 청능재활의 도구로 사용하는 보청 기의 효과를 확인할 수 있어 임상적으로 의의가 있다고 할 수 있다.

청능재활에서 일상생활의 의사소통 증진을 위해 사용될 수 있 는 의사소통의 전략은 크게 촉진 전략(Facilitative strategies)과 수 정 전략(Repair strategies)으로 구별된다. 서론에서 언급한 바와 같 이 촉진 전략은 의사소통 모델의 하위 구성 요소인 화자(Talker), 메시지(Message), 환경(Environment), 환자/청자(Patient)에서 사 용 가능한 전략으로 화자의 지시 전략(Instructional strategies), 메 시지 구성 전략(Message-tailoring strategies), 환경을 변화시키는 전략인 구조 전략(Constructive strategies), 환자의 메시지 수용에 미치는 전략인 적응 전략(Adaptive strategy)과 예기 전략(Anticipatory strategy) 등이 있다. 수정 전략에는 수용적 수정 전략(Receptive repair strategy)과 표현적 수정 전략(Expressive repair strategy)이 있다. 청능재활에서 K-CSOA를 사용할 경우 난청인은 자신이 가장 빈번하게 사용하는 의사소통 전략을 알 수 있고 어떤 전략을 개선해야 하는 지를 분명히 인지할 수 있다. 더불어 난청인 은 청각보조기기인 보청기나 인공와우 착용 전후 자신의 의사소통 전략의 실제에 대한 분명한 인식을 가질 수 있다. $\mathrm{K}-\mathrm{CSOA}$ 의 평가 결과로 난청인이 부족한 의사소통 전략은 훈련을 통하여 일상생활 에서의 의사소통은 훨씬 원활하게 촉진될 수도 있다.

$\mathrm{K}-\mathrm{CSOA}$ 는 의사소통의 전략 이외에 의사소통의 태도에 대한 중 요한 임상 정보를 제공한다. K-CSOA의 의사소통태도 척도는 난청 또는 청력 손실에 대한 난청인 자신의 태도, 가족의 태도, 및 가족 외 다른 사람의 태도에 대한 인식의 조사이며 난청인 자신의 태도 항목에서만 세부항목으로 난청 또는 청력 손실에 대한 수치 (Shame), 분노(Anger), 수용(Accept), 긴장(Tension), 우울(Depression)에 대한 평가로 구성되었다. 따라서 K-CSOA의 의사소통태도 척도는 난청인이 자신의 청력손실에 대해 어떻게 느끼는 지와 함께 다른 사람이 난청에 어떻게 반응하는지에 대한 인식을 평가한다. 이러한 인식은 난청이 개인, 가족 및 타인에게 어떤 영향을 미치고 이러한 감정과 태도를 보청기와 인공와우와 같은 청각보조기기를 사용할 때 어떻게 변화되고 극복될 수 있는 지를 보여준다.

본 연구는 건청 노인과 난청 노인을 대상으로 K-CSOA의 의사소 통 전략과 태도를 비교하였을 때 난청 노인의 의사소통 전략과 태 도의 총 점수가 유의미하게 높은 결과를 보였다. 이것은 난청 노인 이 더 많은 의사소통 전략, 의사소통 태도 및 의사소통 사용에 어려 움 또는 문제가 있음을 보여주고 있다. 청능재활에서는 난청 노인 의 이러한 문제점을 직시하여 다양한 의사소통 전략과 태도를 개 선할 수 있는 프로그램을 개발할 필요성이 있음을 시사한다. 비록 
본 연구는 연구대상으로 난청 노인의 의사소통 전략과 태도 특성 을 나타내지만 나이의 많고 적음을 떠나 전체 난청인의 의사소통 전략과 태도의 특성도 보여준다고도 할 수 있다. 따라서 청능재활 의 프로그램에 난청인을 위한 의사소통의 전략과 태도 변화에 초 점을 두고 강조할 필요가 있음을 나타낸다. 본 연구로 개발된 $\mathrm{K}-$ $\mathrm{CSOA}$ 의 설문지가 다양한 장애인이나 정상인들을 대상으로 의사 소통 전략과 태도에 대한 평가도구로 임상적으로 사용될 수 있기 를 기대한다.

이와 같은 본 연구의 의의에도 불구하고, 본 연구에는 제한점이 있으며, 본 연구와 제한점 및 후속연구를 위한 제안은 아래와 같다. 첫 번째, 본 연구는 부산, 대구, 경북 지역에 거주하는 노인 60 명의 연구결과로 대상자의 수가 적고 대상자의 성격 및 감정 등 주관적 인 요소가 반영된 것으로 일반화하여 해석하는 것은 어려움이 있 다. 따라서 추후연구에서는 대상자 수를 늘리고 고도와 심도 난청 인의 수를 보완하여 난청의 정도에 따른 후속연구를 수행하도록 제안한다. 두 번째, 본 연구는 한국어판 노인의 의사소통척도의 타 당도와 신뢰도를 구하는 연구였다. 대상자들은 60 대 이상의 고령 자들 이였으며, 청력만 노화로 나빠진 것이 아닌 시력 또한 노화로 나빠져 있는 사람이 대다수였으며, 한글을 읽지 못하는 사람들도 있어서 대다수 대상자들이 연구자가 질문을 읽어주고 대상자가 대 답을 하면 연구자가 기록하는 방식(Face to Face)으로 설문지를 작 성하였다. 이에 추후 연구에서는 대상자들이 설문지를 직접 읽을 수 있도록 글자 크기를 14pt 이상(Bahng, 2017)으로 설문지를 제작 하여 후속연구를 제안한다. 세 번째, 한국어판 노인의 의사소통척 도의 전략 척도와 태도 척도의 총 문제 수가 72 문제여서 설문지를 작성하는데 대략적으로 30 분 정도가 걸렸다. 그러하여 처음부터 설문지를 작성 안 해주는 경우가 많았으며, 중도에 포기하는 사람 들도 있었다. 이에 더욱 적은 문항의 단축형 설문지를 제작하여, 연 구를 진행하는 후속연구를 제안한다. 마지막으로 본 연구에서는 주관적인 검사지표만 사용하였으므로 추후에는 객관적인 검사지 표를 함께 사용하는 후속연구를 제안한다.

\section{REFERENCES}

Alexander, D., Wetherby, A., \& Prizant, B. (1997). The emergence of repair strategies in infants and toddlers. Seminars in Speech and Language, 18(3), 197-212.

Bahng, J. W. (2017). Aural rehabilitation. In Korean Association of Audiology Professor (Ed.). Introduction to audiology. Seoul: Hakjisa.

Chu, H. S., Cho, Y. S., Park, S. N., Byun, J. Y., Shin, J. U., Han, G. C., ... \&
Jung, J. Y. (2012). Standardization for a Korean adaptation of the international outcome inventory for hearing aids: study of validity and reliability. Korean Society of Otorhinolaryngology-Head and Neck Surgery, 55(1), 20 25.

Demorest, M. E., \& Erdman, S. A. (1987). Development of the communication profile for the hearing impaired. Journal of Speech and Hearing Disorders, 52(2), 129-142.

Gomez, R. G., \& Madey, S. F. (2001). Coping with hearing loss model for older adults. Journal of Gerontology: Pyschological Sciences, 56(4), 223-225.

Gordon-Salant, S. (2005). Hearing loss and aging: new research findings and clinical implications. Journal of Rehabilitation Research and Development, $42(4), 9-24$.

Han, W., Lee D., Koo, M., \& Kim, J. S. (2015). Questionnaires for the hearingimpaired adults and elderly: a systematic literature review, Audiology, 11(1), 3-16.

Jang, H. S., Cho, S. J., Kim, U. K., \& Choi, J. H. (2018). Foundations of aural rehabilitation: children, adults, and their family members, Seoul: Bakhak Co.

Jaworski, A., \& Stephens, D. (1998). Self-reports on silence as a face-saving strategy by people with hearing impairment. International Journal of Applied Linguistics, 8(1), 61-80.

Jin, J. H. (2000). Korean usage of communication strategies in interactive situations for foreign learners. Bilingual Research, 17, 339-358.

Kaplan, K., Bally, S., Brandt, F., Busacco, D., \& Pray, J. (1997). Communication scale for older adults. Journal of the American Academy of Audiology, 8(3), 203-217.

Khoo, H. L., \& Kim, J. S. (2000). Test-retest reliability of KHHIE for aging related hearing loss in Korea. Korean Journal of Communication Disorders, 5(1), 133-154

Kim, G. G., Lee, U. S., Kim, D. K., \& Kim, J. S. (2018). An Analysis Study of Features for Hearing Aid Satisfaction Questionnaires: Satisfaction with Amplification in Daily Life, Client Oriented Scale of Improvement, International Outcome Inventory for Hearing Aids. Audiology and Speech Research, 14(3), 158-175.

Kim, T. W., Shim, S. Y., \& Lee, K. W. (2016). Development of Korean version of profile of hearing aid benefit. Audiology and Speech Research, 12(4), 209-220.

Korea Institute for Health and Social Affairs. (2018). 2017 Survey on Seniors. Sejong: Author.

Lamb, S. H., Owens, E., \& Schubert, E. D. (1983). The revised form of the 
hearing performance inventory. Ear and Hearing, 4(3), 152-157.

Laplate-Lévesque, A., Hickson L., \& Worrall, L. (2011). Predictors of rehabilitation intervention decisions in adults with acquired hearing impairment. Journal of Speech, Language, and Hearing Research, 54(5), 1385-1399

Lim, H. W., \& Chae, S. W. (2011). The current state of age-related hearing loss in South Korea. Journal of the Korean Medical Association, 54(9), 910917.

Moseley, M. J., \& Bally, S. J. (1996). Communication therapy. Washington, DC: Gallaudet University press.

Prendergast, S. G., \& Kelly, L. A. (2002). Aural rehab services: survey reports who offers which ones and how often. The Hearing Journal, 55(9), 30-35.
Statistics Korea. (2020). Statistics on Seniors. Daejeon: Author.

Suk, D. I. (2004). The development of communication scale content for prebycusis. Communication Disorder, 27(1), 39-63.

Sweetow, R. W., \& Sabes, J. H. (2006). The need for and development of an adaptive listening and communication enhancement (LACE $\left.{ }^{\mathrm{m}}\right)$ Program. Journal of the American Academy of Audiology, 17(8), 538-558.

Tye-Murray, N. (2009). Foundations of aural rehabilitation: children, adults, and their family members (3rd ed.). New York, NY: Delmar Cengage Learning.

Yorkston, K. M., Bourgeois, M. S., \& Baylor, C. R. (2010). Communication and aging. Physical Medicine \& Rehabilitation Clinics, 21(2), 309-319. 
Appendix 1. 한국어판 노인의 의사소통 척도

\section{의사소통 전략 Communication Strategies}

1. 모르는 사람과 대화할 때 무슨 말인지 이해가 되지 않으면 다시 말해달라고 요청한다.

(1) 항상 그렇다 (2) 그렇다 (3) 보통이다 (4) 그렇지 않다 (5) 전혀 그렇지 않다

*2. 두 명의 사람들과 대화할 때 대화하는 내용이 이해가 되지 않으면, 대화주제를 변경하여 대화를 주도한다.

(1) 항상 그렇다 (2) 그렇다 (3) 보통이다 (4) 그렇지 않다 (5) 전혀 그렇지 않다

3. 낯선 사람에게 길을 물었을 때 답변의 일부만 이해할 수 있으면 이해한 부분만 말하고 이해하지 못한 부분은 다시 말해달라고 요청한다.

(1) 항상 그렇다 (2) 그렇다 (3) 보통이다 (4) 그렇지 않다 (5) 전혀 그렇지 않다

4. 친구가 새로운 사람을 소개할 때 이름을 적어달라고 요청한다.

(1) 항상 그렇다 (2) 그렇다 (3) 보통이다 (4) 그렇지 않다 (5) 전혀 그렇지 않다

5. 낯선 사람이 자신의 이름을 말해줄 때 그 중 성이나 이름을 잘 알아듣지 못한 경우 다시 말해달라고 요청한다.

(1) 항상 그렇다 (2) 그렇다 (3) 보통이다 (4) 그렇지 않다 (5) 전혀 그렇지 않다

6. 어떤 사람이 자신의 주소를 알려줄 때 이해하지 못한 경우 번지수를 한 숫자씩 반복 해달라고 요청한다.

(1) 항상 그렇다 (2) 그렇다 (3) 보통이다 (4) 그렇지 않다 (5) 전혀 그렇지 않다

*7. 한 사람과 이야기를 하는데 그 사람이 하는 이야기를 이해하지 못할 경우 그 사람의 말이 채 끝나기 전에 가로막고 내 생각을 말한다.

(1) 항상 그렇다 (2) 그렇다 (3) 보통이다 (4) 그렇지 않다 (5) 전혀 그렇지 않다

8. 친구가 햄버거 7개를 사오라고 부탁했는데, 그 숫자를 이해하지 못할 때 친구에게 숫자를 0 부터 세어 원하는 햄버거의 숫자에서 멈춰달라고 요청한다.

(1) 항상 그렇다 (2) 그렇다 (3) 보통이다 (4) 그렇지 않다 (5) 전혀 그렇지 않다

*9. 모임에 참석했는데, 연사가 말하는 것을 일부 이해하지 못하는 경우 이해하는 척하고 나중에 정보를 얻기를 바란다.

(1) 항상 그렇다 (2) 그렇다 (3) 보통이다 (4) 그렇지 않다 (5) 전혀 그렇지 않다

10. 두 명의 사람들과 대화 시 이해하지 못할 때 그들에게 말하는 주제가 무엇인지 물어본다.

(1) 항상 그렇다 (2) 그렇다 (3) 보통이다 (4) 그렇지 않다 (5) 전혀 그렇지 않다

11. 식당에서 한 사람과 이야기를 하는데 상대방의 얼굴이 그림자에 가려져 있을 때 자리를 바꾸면 상대방의 말을 더 잘 알아들을 것 같아 자리를 바꾸자고 한다.

(1) 항상 그렇다 (2) 그렇다 (3) 보통이다 (4) 그렇지 않다 (5) 전혀 그렇지 않다

12. 병원을 방문했을 때 의사가 질병에 대처하는 방법을 말할 때 의사의 말을 이해하지 못해 써달라고 요청한다.

(1) 항상 그렇다 (2) 그렇다 (3) 보통이다 (4) 그렇지 않다 (5) 전혀 그렇지 않다

*13. 모임에 참석 중 연사가 당신 쪽을 보지 않고 말하면 화가 나지만 아무 것도 하지 않는다.

(1) 항상 그렇다 (2) 그렇다 (3) 보통이다 (4) 그렇지 않다 (5) 전혀 그렇지 않다

14. 모임 참석 중 너무 멀리 앉아서 연사의 말을 알아들을 수 없을 때 비어있는 앞 좌석으로 이동한다.

(1) 항상 그렇다 (2) 그렇다 (3) 보통이다 (4) 그렇지 않다 (5) 전혀 그렇지 않다

*15. 모임에서 유일한 난청인으로 말이 이해가 되지 않지만 두려워 도움을 요청하지 않고 혼자 최선을 다한다.

(1) 항상 그렇다 (2) 그렇다 (3) 보통이다 (4) 그렇지 않다 (5) 전혀 그렇지 않다

16. 치과의사와 진료상담 중 의사는 말이 너무 빨라 입모양을 읽을 수 없을 때 천천히 말해달라고 요청한다.

(1) 항상 그렇다 (2) 그렇다 (3) 보통이다 (4) 그렇지 않다 (5) 전혀 그렇지 않다 
17. 수업 중 교사가 칠판에 글을 쓰면서 말할 경우 수업 후에 입모양을 읽으려면 얼굴을 봐야한다고 말한다.

(1) 항상 그렇다 (2) 그렇다 (3) 보통이다 (4) 그렇지 않다 (5) 전혀 그렇지 않다

18. 강의실에서 돌아다니면서 강의하는 강사의 입모양을 읽는데 문제가 있을 경우 강의 후 상담요청을 한 후 움직이지 않고 강의해달라고 요청한다.

(1) 항상 그렇다 (2) 그렇다 (3) 보통이다 (4) 그렇지 않다 (5) 전혀 그렇지 않다

19. 연속적인 모임이나 강의에 참석할 경우 강사에게 가능한 슬라이드, 그림 또는 빔프로젝터를 사용하도록 요청한다.

(1) 항상 그렇다 (2) 그렇다 (3) 보통이다 (4) 그렇지 않다 (5) 전혀 그렇지 않다

20. 연속적인 모임이나 강의에 참석할 경우 강사에게 대신 필기를 할 수 있는 사람을 요청한다.

(1) 항상 그렇다 (2) 그렇다 (3) 보통이다 (4) 그렇지 않다 (5) 전혀 그렇지 않다

21. 연속적인 모임이나 강의에 참석할 경우 강의의 개요 또는 독서 리스트를 요청한다.

(1) 항상 그렇다 (2) 그렇다 (3) 보통이다 (4) 그렇지 않다 (5) 전혀 그렇지 않다

22. 연극공연에 참석할 경우 연극을 보기 전에 극본을 읽거나 그 연극에 대한 평론을 미리 읽는다.

(1) 항상 그렇다 (2) 그렇다 (3) 보통이다 (4) 그렇지 않다 (5) 전혀 그렇지 않다

23. 은행의 직원과 이야기할 때 소방차가 지나가면 직원에게 소방차 소음이 사라질 때까지 말을 멈추어 달라고 요청한다.

(1) 항상 그렇다 (2) 그렇다 (3) 보통이다 (4) 그렇지 않다 (5) 전혀 그렇지 않다

*24. 상대방이 말하는 것을 이해하지 못해 다시 말해달라고 요청할 때 상대방이 언짢아하면 부탁한 것을 멈추고 상대방의 말을 이해한 척 한다.

(1) 항상 그렇다 (2) 그렇다 (3) 보통이다 (4) 그렇지 않다 (5) 전혀 그렇지 않다

25. 낯선 사람에게 길을 묻는데 그 사람의 말을 꼭 알아들어야할 경우 “그곳은 여기로부터 남쪽에 있나요, 아니면 북쪽에 있나요?” 와 같이 매우 구체적으로 질문한다.

(1) 항상 그렇다 (2) 그렇다 (3) 보통이다 (4) 그렇지 않다 (5) 전혀 그렇지 않다

26. 낯선 사람에게 길을 물을 때 이해를 잘 하지 못할 것을 걱정해서 낯선 사람에게 길을 물어 보는 것을 피한다.

(1) 항상 그렇다 (2) 그렇다 (3) 보통이다 (4) 그렇지 않다 (5) 전혀 그렇지 않다

27. 가게 안에 있는데 점원의 목소리가 너무 작아서 듣는 데 어려움이 있을 경우 청각 장애가 있으니 더 크게 말하도록 요청한다.

(1) 항상 그렇다 (2) 그렇다 (3) 보통이다 (4) 그렇지 않다 (5) 전혀 그렇지 않다

28. 가족이나 친구들에게 말을 하기 전에 먼저 당신의 주의를 끌라고 요청한다.

(1) 항상 그렇다 (2) 그렇다 (3) 보통이다 (4) 그렇지 않다 (5) 전혀 그렇지 않다

29. 5-6명의 친구와 함께 있는데 그들이 말하는 것 중 무언가 중요한 것을 놓쳤을 때 옆에 있는 친구에게 무슨 말을 했는지 물어본다.

(1) 항상 그렇다 (2) 그렇다 (3) 보통이다 (4) 그렇지 않다 (5) 전혀 그렇지 않다

30. 껌을 씹고 있는 상대방의 말을 이해하지 못할 경우 상대방에게 입모양을 읽어야 (독화) 하니 껌을 씹지 말아 달라고 예의를 갖춰서 부탁한다.

(1) 항상 그렇다 (2) 그렇다 (3) 보통이다 (4) 그렇지 않다 (5) 전혀 그렇지 않다

*31. 말하는 것을 잘 이해하지 못할 것이라고 예상되는 사람과는 대화를 꺼린다.

(1) 항상 그렇다 (2) 그렇다 (3) 보통이다 (4) 그렇지 않다 (5) 전혀 그렇지 않다

*32. 청력 문제로 다른 사람들을 피해주는 것이 싫어서 알아들은 척 한다.

(1) 항상 그렇다 (2) 그렇다 (3) 보통이다 (4) 그렇지 않다 (5) 전혀 그렇지 않다

*33. 보청기 착용하면 느낌이 다르기 때문에 착용하는 것을 기피한다.

(1) 항상 그렇다 (2) 그렇다 (3) 보통이다 (4) 그렇지 않다 (5) 전혀 그렇지 않다

34. 많은 관심을 가지고 있는 주제에 대한 강의에 참석했는데, 마이크가 있지만 강사가 사용하지 않을 경우 손을 들어 강사에게 마이크를 사용하도록 요청한다.

(1) 항상 그렇다 (2) 그렇다 (3) 보통이다 (4) 그렇지 않다 (5) 전혀 그렇지 않다 
*35. 많은 관심을 가지고 있는 주제에 대한 강의에 참석했는데 마이크가 있지만 이해 할 수 있을 만큼 강도가 크게 설정되지 않았을 경우 화가 난 채로 강연장을 떠나면 서 "책임자"에게 불평한다.

(1) 항상 그렇다 (2) 그렇다 (3) 보통이다 (4) 그렇지 않다 (5) 전혀 그렇지 않다

*36. 많은 관심을 가지고 있는 주제에 대한 강의에 참석했는데 강사가 너무 빨리 말해서 이해할 수가 없는 경우 시간 낭비라 생각되어 강의 빠져나온다.

(1) 항상 그렇다 (2) 그렇다 (3) 보통이다 (4) 그렇지 않다 (5) 전혀 그렇지 않다

*37. 많은 관심을 가지고 있는 주제에 대한 강의에 참석했는데 강사가 너무 많이 움직여서 강사의 말을 이해하는 데 어려움이 있을 경우 강의가 끝난 후 주최 측에 항의 를 한다.

(1) 항상 그렇다 (2) 그렇다 (3) 보통이다 (4) 그렇지 않다 (5) 전혀 그렇지 않다

*38. 명절의 식탁에서 모든 사람이 한꺼번에 말을 하려고 할 경우 대화를 알아들을 수 없어 내년에는 이런 자리에 참석하지 않으리라 다짐한다.

(1) 항상 그렇다 (2) 그렇다 (3) 보통이다 (4) 그렇지 않다 (5) 전혀 그렇지 않다

39. 명절의 식탁에서 모든 사람이 한꺼번에 말을 하려고 하면 대화를 알아들을 수 없기 때문에 모든 사람이 주목하도록 하고 본인의 청력 문제를 설명하고 돌아가면서 한 사람씩 말하게 하여 대화를 이해할 수 있도록 요청한다.

(1) 항상 그렇다 (2) 그렇다 (3) 보통이다 (4) 그렇지 않다 (5) 전혀 그렇지 않다

40. 명절의 식탁에서 모든 사람이 한꺼번에 말을 하려고 하면 대화를 알아들을 수 없어 저녁을 주최한 사람에게 문제를 설명하여 그가 상황을 처리하도록 요청한다.

(1) 항상 그렇다 (2) 그렇다 (3) 보통이다 (4) 그렇지 않다 (5) 전혀 그렇지 않다

*41. 명절의 식탁에서 모든 사람이 한꺼번에 이야기하기 때문에 대화를 이해할 수 없을 경우 파티에 있는 것 자체가 즐거워 아무 말도 하지 않습니다.

(1) 항상 그렇다 (2) 그렇다 (3) 보통 이다 (4) 그렇지 않다 (5) 전혀 그렇지 않다

\section{의사소통 태도 Communication Attitudes}

1. 상대방의 말을 이해하지 못하면 당황스럽게 느낀다.

(1) 전혀 그렇지 않다 (2) 그렇지 않다 (3) 보통이다 (4) 그렇다 (5) 항상 그렇다

2. 대화의 내용을 이해하지 못하면 화가 난다.

(1) 전혀 그렇지 않다 (2) 그렇지 않다 (3) 보통이다 (4) 그렇다 (5) 항상 그렇다

3. 이해할 수 있을 만큼 상대방이 명확하게 말하지 않으면 화가 난다.

(1) 전혀 그렇지 않다 (2) 그렇지 않다 (3) 보통이다 (4) 그렇다 (5) 항상 그렇다

4. 상대방이 하는 말을 오해했을 때 나 스스로 어리석다고 느낀다.

(1) 전혀 그렇지 않다 (2) 그렇지 않다 (3) 보통이다 (4) 그렇다 (5) 항상 그렇다

5. 누군가에게 다시 말해달라고 요청하기가 어려울 경우 당황스럽게 느낀다.

(1) 전혀 그렇지 않다 (2) 그렇지 않다 (3) 보통이다 (4) 그렇다 (5) 항상 그렇다

6. 대부분의 사람들은 내가 더 주의를 기울이면 더 잘 이해할 수 있다고 생각한다.

(1) 전혀 그렇지 않다 (2) 그렇지 않다 (3) 보통이다 (4) 그렇다 (5) 항상 그렇다

7. 나는 사람들이 너무 작은 소리로 말하거나 빠른 속도로 말하면 화가 난다.

(1) 전혀 그렇지 않다 (2) 그렇지 않다 (3) 보통이다 (4) 그렇다 (5) 항상 그렇다

*8. 때로는 식구들의 대화 내용을 이해하지 못하지만, 나는 여전히 가족생활의 한 부분으로 여긴다.

(1) 전혀 그렇지 않다 (2) 그렇지 않다 (3) 보통이다 (4) 그렇다 (5) 항상 그렇다

9. 사람들과의 의사소통을 시도할 때 짜증이 난다.

(1) 전혀 그렇지 않다 (2) 그렇지 않다 (3) 보통이다 (4) 그렇다 (5) 항상 그렇다 
10. 대부분의 사람들은 난청인이 된 다는 것이 어떤 것인지 이해하지 못하므로 그것이 화가 난다.

(1) 전혀 그렇지 않다 (2) 그렇지 않다 (3) 보통이다 (4) 그렇다 (5) 항상 그렇다

11. 청각장애인 것이 부끄럽다.

(1) 전혀 그렇지 않다 (2) 그렇지 않다 (3) 보통이다 (4) 그렇다 (5) 항상 그렇다

12. 상대방이 입을 가리거나 등을 돌리고 말할 때 화가 난다.

(1) 전혀 그렇지 않다 (2) 그렇지 않다 (3) 보통이다 (4) 그렇다 (5) 항상 그렇다

13. 대부분의 시간을 혼자 보내는 것을 좋아한다.

(1) 전혀 그렇지 않다 (2) 그렇지 않다 (3) 보통이다 (4) 그렇다 (5) 항상 그렇다

14. 청력이 손실되었다는 사실은 나를 초조하게 만든다.

(1) 전혀 그렇지 않다 (2) 그렇지 않다 (3) 보통이다 (4) 그렇다 (5) 항상 그렇다

15. 청력이 손실되었다는 사실은 나를 우울하게 만든다.

(1) 전혀 그렇지 않다 (2) 그렇지 않다 (3) 보통이다 (4) 그렇다 (5) 항상 그렇다

16. 우리 가족은 나의 청력 손실에 대해 이해하지 못한다.

(1) 전혀 그렇지 않다 (2) 그렇지 않다 (3) 보통이다 (4) 그렇다 (5) 항상 그렇다

17. 난청 때문에 사람들이 나에게 고함치듯 말할 때는 화가 난다.

(1) 전혀 그렇지 않다 (2) 그렇지 않다 (3) 보통이다 (4) 그렇다 (5) 항상 그렇다

18. 사람들은 내가 그들의 말을 이해하지 못할 때 나를 바보 같은 사람으로 여긴다.

(1) 전혀 그렇지 않다 (2) 그렇지 않다 (3) 보통이다 (4) 그렇다 (5) 항상 그렇다

19. 청각장애가 있는 사람들은 종종 의사소통에 어려움을 겪는데 정상청력을 가진 사람만이 의사소통을 개선할 수 있다.

(1) 전혀 그렇지 않다 (2) 그렇지 않다 (3) 보통이다 (4) 그렇다 (5) 항상 그렇다

20. 청각장애가 있는 사람들은 종종 의사소통에 어려움을 겪는데 난청을 가진 사람만이 의사소통을 개선할 수 있다.

(1) 전혀 그렇지 않다 (2) 그렇지 않다 (3) 보통이다 (4) 그렇다 (5) 항상 그렇다

21. 나의 가족들은 자신들이 말하는 것을 내가 알아듣지 못할 때 화를 낸다.

(1) 전혀 그렇지 않다 (2) 그렇지 않다 (3) 보통이다 (4) 그렇다 (5) 항상 그렇다

22. 내가 청력 손실이 있다는 것을 아는 사람들은 내가 듣고 싶은 의지만 있다면 들을 수 있다고 생각한다.

(1) 전혀 그렇지 않다 (2) 그렇지 않다 (3) 보통이다 (4) 그렇다 (5) 항상 그렇다

23. 우리 가족은 대화할 때 나를 제외시킨다.

(1) 전혀 그렇지 않다 (2) 그렇지 않다 (3) 보통이다 (4) 그렇다 (5) 항상 그렇다

*24. 보청기는 사람들이 말을 이해하는 데 항상 도움이 되는 것은 아니지만 다른 방식으로도 도움을 줄 수 있다

(1) 전혀 그렇지 않다 (2) 그렇지 않다 (3) 보통이다 (4) 그렇다 (5) 항상 그렇다

*25. 대화 시 입모양 읽기(독화)가 도움이 된다고 생각한다.

(1) 전혀 그렇지 않다 (2) 그렇지 않다 (3) 보통이다 (4) 그렇다 (5) 항상 그렇다

26. 사람들은 내가 청력을 잃었다는 것을 알고 있지만 명확하게 말하거나 다시 말해 줌으로써 도와주지는 않는다.

(1) 전혀 그렇지 않다 (2) 그렇지 않다 (3) 보통이다 (4) 그렇다 (5) 항상 그렇다

*27. 우리 가족은 기꺼이 나를 대신해서 전화통화를 해준다.

(1) 전혀 그렇지 않다 (2) 그렇지 않다 (3) 보통이다 (4) 그렇다 (5) 항상 그렇다 
*28. 우리 가족은 내가 말을 이해할 수 없을 때 필요한 만큼 반복해서 말해준다.

(1) 전혀 그렇지 않다 (2) 그렇지 않다 (3) 보통이다 (4) 그렇다 (5) 항상 그렇다

29. 정상 청력을 가진 사람들은 내가 그들이 말하는 것을 이해하지 못할 때 실망한다.

(1) 전혀 그렇지 않다 (2) 그렇지 않다 (3) 보통이다 (4) 그렇다 (5) 항상 그렇다

*30. 우리 가족은 내가 쉽게 입모양(독화)을 읽을 수 있도록 도와준다.

(1) 전혀 그렇지 않다 (2) 그렇지 않다 (3) 보통이다 (4) 그렇다 (5) 항상 그렇다

*31. 낯선 사람들은 내가 쉽게 입모양(독화)을 읽을 수 있도록 도와준다.

(1) 전혀 그렇지 않다 (2) 그렇지 않다 (3) 보통이다 (4) 그렇다 (5) 항상 그렇다 


\section{국문초록}

\section{한국어판 노인의 의사소통척도의 신뢰도와 타당도}

노진영 ${ }^{1} \cdot$ 최성희 ${ }^{1,2,3} \cdot$ 이경재 $^{1,2,3} \cdot$ 최철희 ${ }^{1,2,3}$

${ }^{1}$ 언어청각치료학과, 대구가톨릭대학교, ${ }^{2}$ 가톨릭 청각음성언어센터, 대구가톨릭대학교, ${ }^{3}$ 생체모방감각제어연구소, 대구가톨릭대학교

배경 및 목적: 청능재활은 난청과 관련된 일상생활의 어려움을 축소하고 일상생활에서 난청의 결과를 최소화하기 위한 목적으로 수행 된다. 청능재활은 난청의 진단과 확인, 보청기와 인공와우 같은 적절한 청각보기기기의 제공, 청능훈련, 독화 및 의사소통 전략을 포함 한다. 의사소통 전략은 대화의 상호작용을 촉진하고 의사소통 문제를 수정하기 위해 취해진 일련의 활동과정을 의미하지만 다른 구성 요소에 비해 상대적으로 의사소통 전략은 일상생활에서의 그 중요성에도 불구하고 하나의 의미있는 평가도구로 발전되지 못한 실정이 다. 따라서 본 연구는 의사소통의 전략과 태도의 변화를 평가하기 위하여 Kaplan 등(1997)에 의해 만들어진 노인의 의사소통척도의 한 국어판을 만들고자 한다. 즉 한국어판 노인의 의사소통척도의 신뢰도와 타당도를 연구하고자 한다. 방법: 한국어판 노인의 의사소통 척도는 의사소통 전략과 의사소통 태도로 구성되어 있고 의사소통 전략은 촉진 전략, 수정 전략, 예비 전략으로 구성되었고 의사소통 태도는 본인, 가족 및 타인의 태도로 구성되었다. 연구참가자는 60 세에서 85 세까지 평균 72 세의 노인들로 정상 청력을 가진 30 명과 다 양한 난청의 정도를 가진 30 명으로 구성된 총 60 명의 노인들로 구성되었다. 결과: 한국어판 노인의 의사소통척도는 피어슨 상관관계계 수, 크론바크 알파계수 및 독립 $t$ 검증에 의해 측정되었다. 의사소통의 총 평균과 하위영역 간의 상관관계계수는 상당히 높았다. $502-$ .984). 의사소통 전략의 내적일관성은 .802 에서 .930이고 의사소통 태도는 .620에서 .962까지였다. 의사소통 전략과 태도의 검사-재검사 상관관계는 .986에서 .988이었다. 더불어 한국어판 노인의 의사소통척도와 한국노인의 청각장애지수(KHHIE)의 상관관계는 .784이었 다. 마지막으로 건청인과 난청인의 의사소통 전략과 태도 점수는 통계적으로 유의미한 차이가 있었다. 논의 및 결론: 그러므로 본 연구 는 한국어판 노인의 의사소총척도가 노인의 의사소통 전략과 태도에 관한 심층적인 정보를 제공하는 유용한 임상도구로 사용될 수 있 음을 보여주고 있다.

핵심어: 청능재활, 한국어판 노인의 의사소통척도, 타당도, 신뢰도. 의사소통 전략, 의사소통 태도 본 연구는 대구가톨릭대학교의 교내연구비(20211182)로 지원되었음.

\section{참고문헌}

구호림, 김진숙 (2000). 한국 노인성난청의 청각장애지수(KHHIE)에 관한 검사-재검사 신뢰도. 언어청각장애연구, 5(1), 133-154.

김건구, 이은성, 김도균, 김진숙 (2018). 보청기 착용 만족도를 측정하는 설문지의 특성 분석 연구. Audiology and Speech Research, 14(3), 158-175. 김태화, 심송용, 이경원 (2016). 한국어판 보청기이득평가 설문지 개발. Audiology and Speech Research, 12(4), 209-220.

방정화 (2017). 청능재활. 한국청각교수협의회 (제2판, 편), 청각학개론 (pp. 291-310). 서울: 학지사.

석동일 (2004). 노인성 난청인의 의사소통 평가 척도 내용 개발 연구. 난청과 언어장애, 27(1), 39-63.

장현숙, 조수진, 김유경, 최재희. (2018). 청능재활의 기초 아동, 성인 및 그들의 가족 구성원(제3판). 서울: 박학사.

임현우, 채성원 (2011). 한국 노화성 난청의 현주소. 대한의사협회지, 54(9), 910-917.

진제희 (2000). 상호 작용 상황에서 나타난 한국어 학습자들의 의사소통 전략양상. 이중언어학, 17,339-358.

추호석, 조양선, 박시내, 변재용, 신정은, 한규철, 천병철, 이준호, 정재윤. (2012). 한국어판 International Outcome Inventory for Hearing Aids (IOI-

$\mathrm{HA}$ )의 표준화: 타당도 및 신뢰도 검증. Korean Society of Otorhinolaryngology-Head and Neck Surgery, 55(1), 20-25.

통계청 (2020). 고령자통계. 대전: 통계청.

한국보건사회연구원 (2018). 2017년도 노인 실태조사. 세종: 한국보건사회연구원. 
한우재, 이동욱, 구미승, 김진숙 (2015). 난청 성인 및 노인용 설문지에 대한 문헌분석. 청능재활, 11(1), 3-16.

\section{ORCID}

노진영(제1저자, 청능사 https://orcid.org/0000-0003-0231-9704), 최성희(공동저자, 교수 https://orcid.org/0000-0003-2365-6187)

이경재(공동저자, 교수 https://orcid.org/0000-0002-6811-1212), 최철희(교신저자, 교수 https://orcid.org/0000-0003-1844-3072) 